\title{
اتجاهات خريجات الاقتصاد نهو العمل \\ بمجال المشروعات الصغيرة وعلاقتها بتحقيق الذات
}

\author{
إعلداد \\ ه. نوره مسفر عطية الزهرانهـ \\ دكتورة بقسم الاقتصاد المنزلي \\ بكلية العلوم والآداب بالمخواه جامعه الباحة
}

مجلة بجوث التربية النوعية - جامعة المنصورة

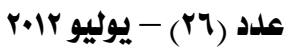


| (إعداد

د . نورهمسفر عطية الزهراني

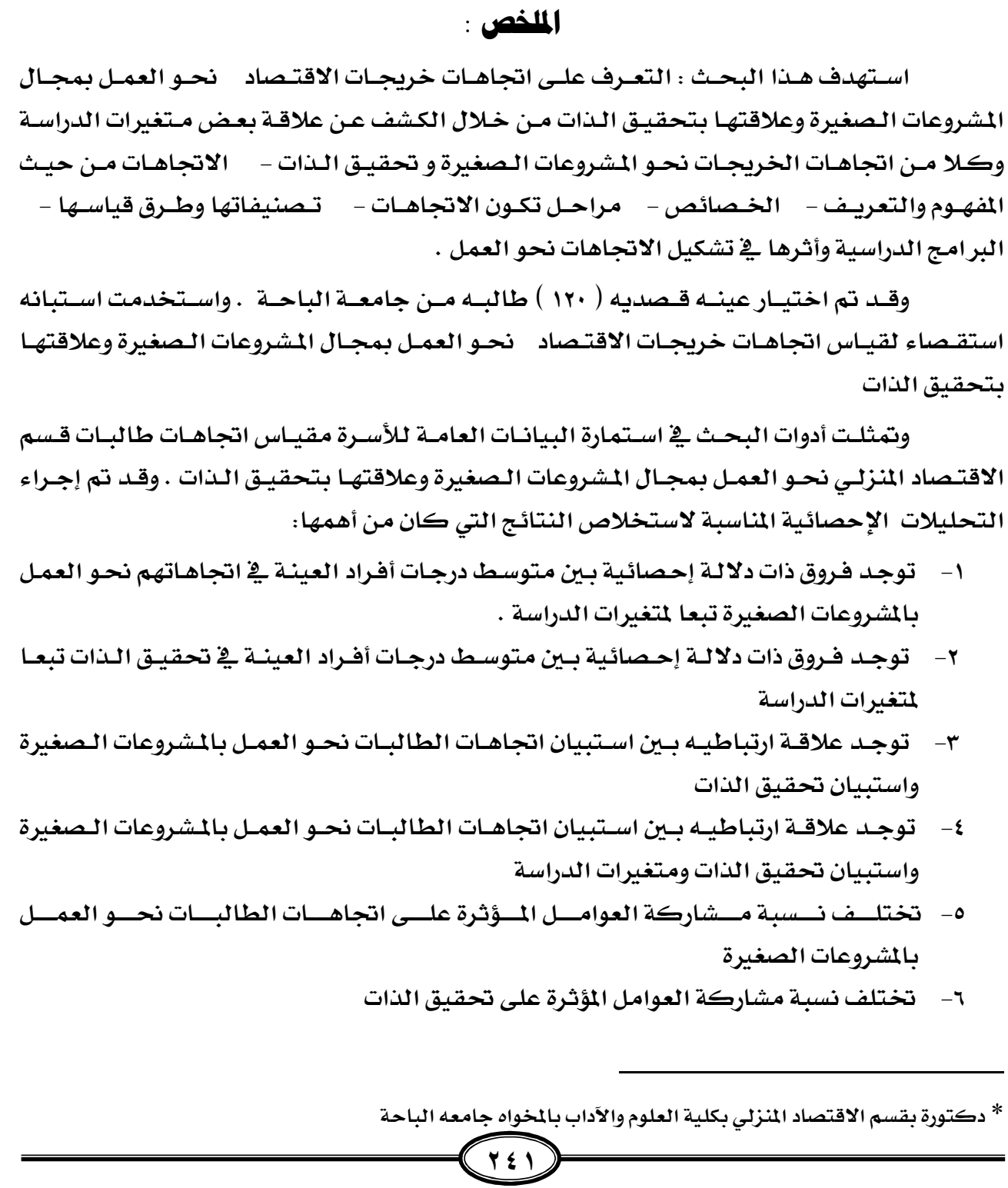




$$
\text { وأوصت الباحثة بالتوصيات التالية: }
$$

ا أن بنـاء اتجاهـات ايجابيـة وعاليـة لدى طالبـات قسهم الاقتصـاد المنزلي نحـو العمـل بالمشروعات

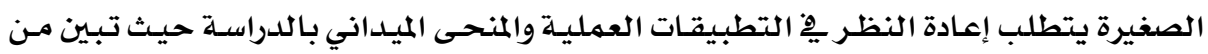

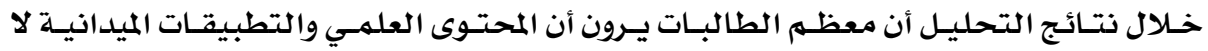

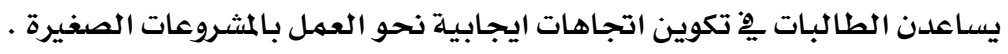

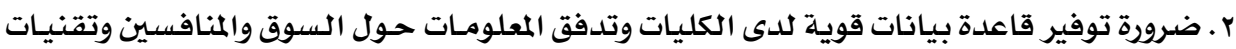

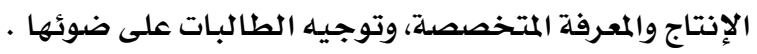

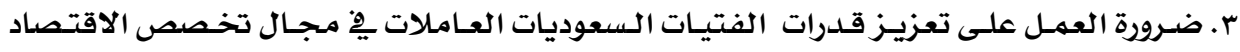
المنزلي، من حيث التوعية بقدراتهن وتشجيعهن للعهمل . 
(إعداد م ـ نورهمسفر عطية الزهراني

تمثل المثروعات الصغيرة إحدى القطاعات الاقتصادية التي تستحوذ على اهتهـام كبير مـن

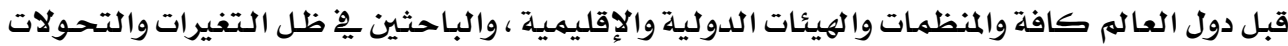

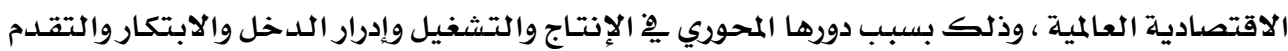

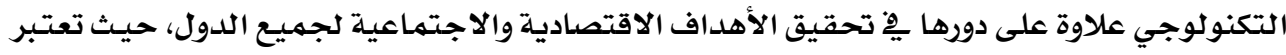

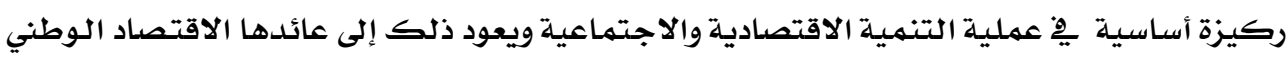

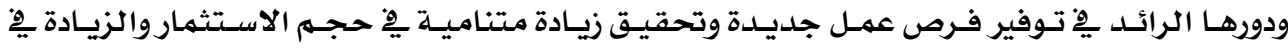

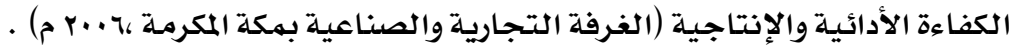

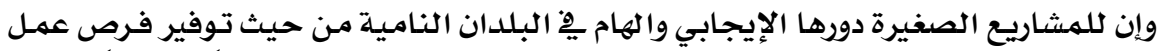

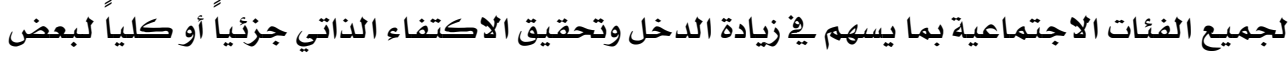

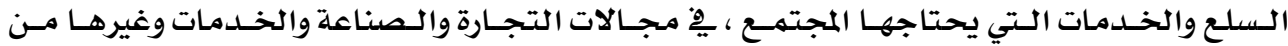

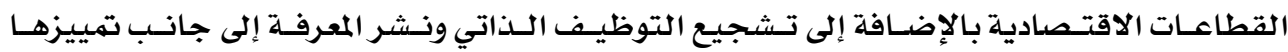

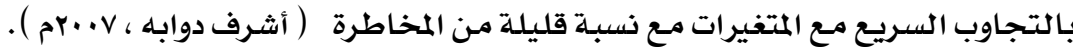

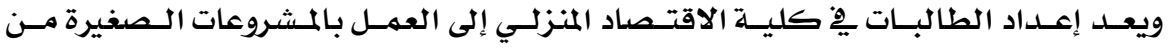

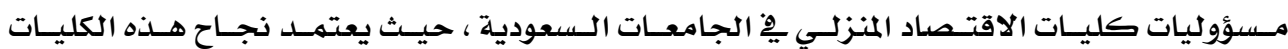
مِ عملها على مـدى قدرتها على تخطيط منـاهـج تريويـة جيدة تستطيع مـن خلالها توجيـه طالبـاتها الوجهة التربوية الصحيحة من حيث التخطيط والتوجيه للعهمل بالمشروعات الصغيرة ، وإن اتجاهـات

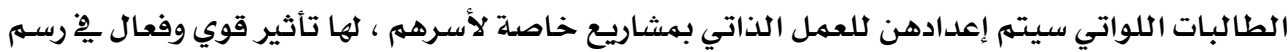
الطريق إمـامهن للدخول يِّ عالم الاقتصاد.

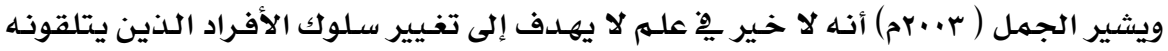
وهذا التغيير يِّ السلوك لا يمكن تحقيقه ما لم تتغير اتجاهات هؤلاء الأفراد . .

وحتى تؤدي طالبـة الاقتصاد المنزلي دورها يِّ الحياة الجامعية فإنه لا بـ من وجـود اتجاهـات

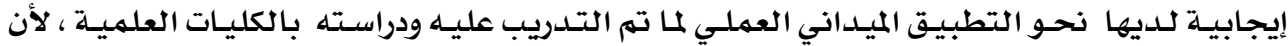




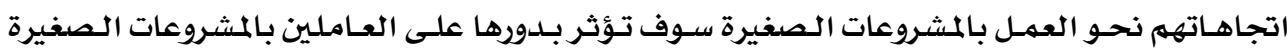

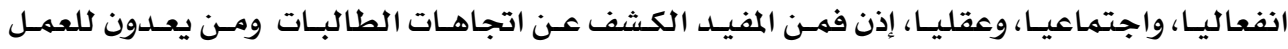

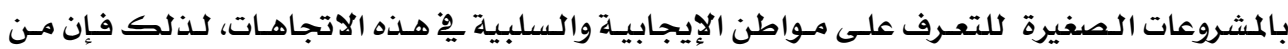

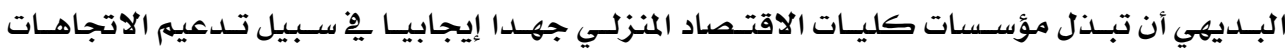

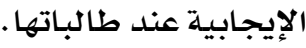

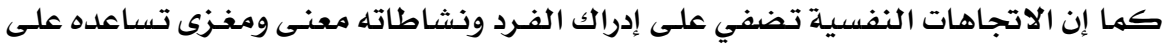

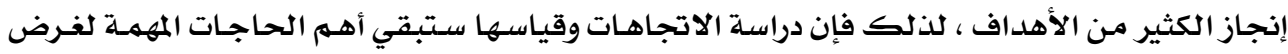

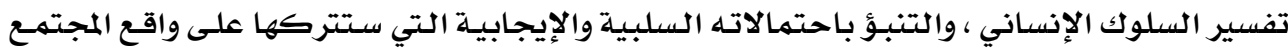

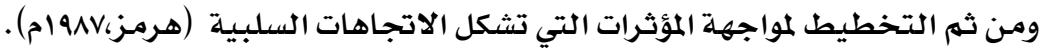

\section{مشكلة الدراسة : من التخطية}

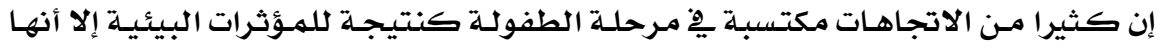

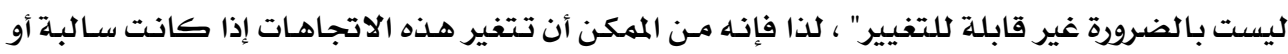

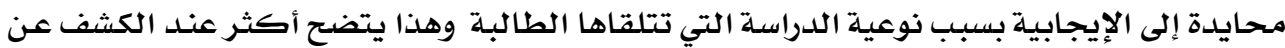

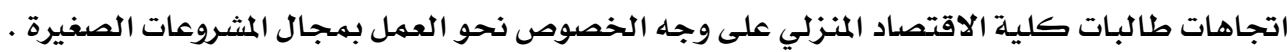

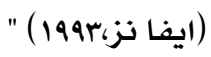

\section{وبِّ ضوء ذلك فأن المشكلة الحقيقة :}

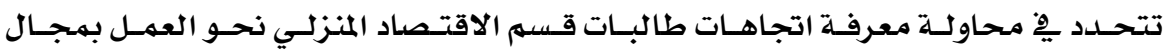

المشروعات الصغيرة ِّْ جامعة الباحة وكذلك الكثف عن علاقة هذه الاتجاهات بتحقيق الذات .

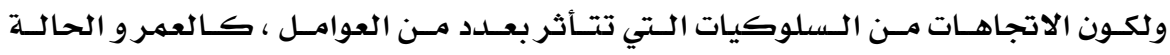

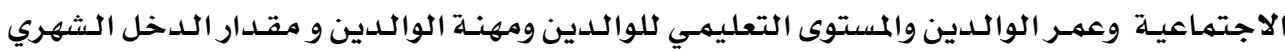

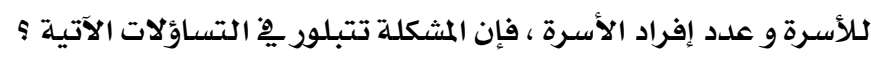

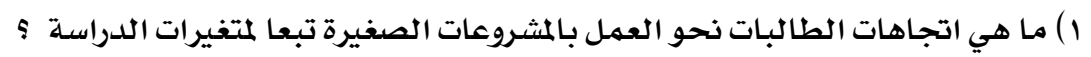

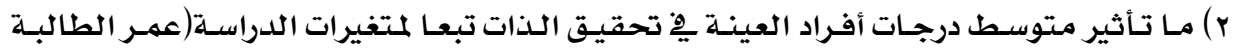

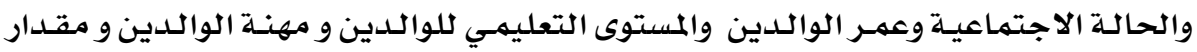
الدخل الشهري للأسرة و عدد إفراد الأسرة) ؟

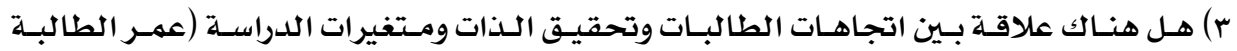

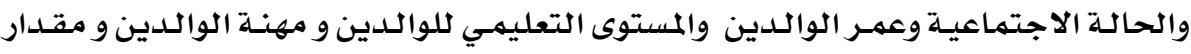

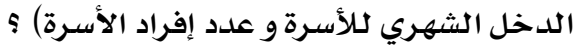

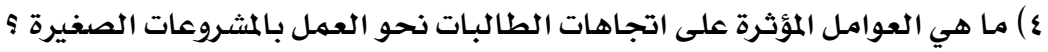

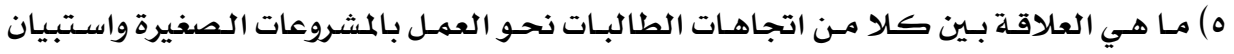

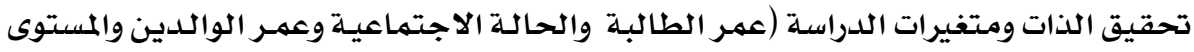
التعليمي للوالدين و مهنة الوالدين و مقدار الدخل الثهري للأسرة و عدد إفراد الأسرة) ؟ 


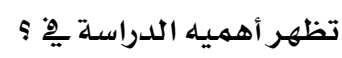

ا ـ التعرّف على اتجاهات الطالبات نحو العهل بالمشروعات الصغيرة .

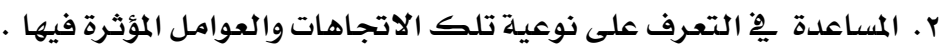

r. توعية الطالبات بأهمية تكوين وبناء اتجاهـات إيجابيـة نحـو العهـل بهجـال المشروعات الصغيرة

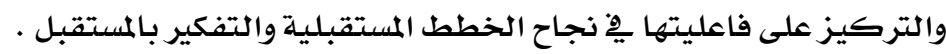

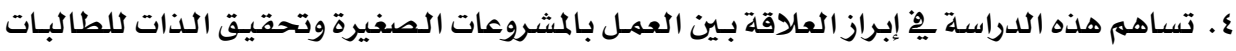

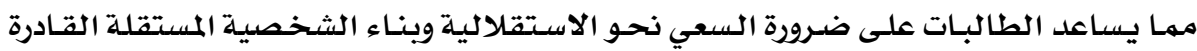

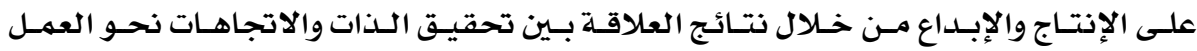

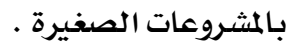

ه. تكتسب الدراسـة أهميـة نظريـة مـن خـلال التعـرف على درجـة مـسـاهمـة المتغيرات الشخـــية

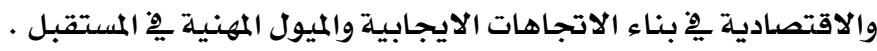

أهداف الدراسة :

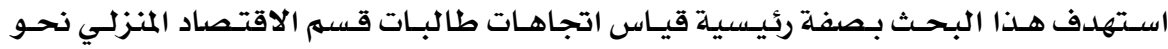

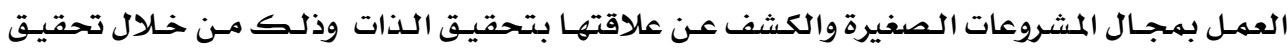

الأهداف الفرعية التالية :

ا- إيجاد الفروق بين متوسط درجات إفراد العينة يخ اتجاهاتهم نحو العمل بالمشروعات الصغيرة

تبعا لمتغيرات الدراسـة .

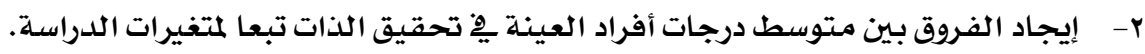

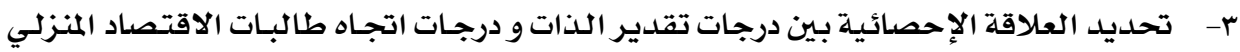

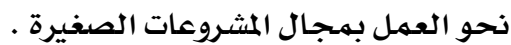

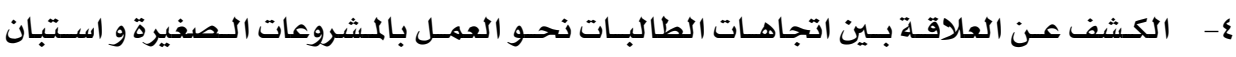

تحقيق الذات.

ه- الكشف عن العلاقة بين اتجـاهـات الطالبـات نحـو العهل بالمشروعات الصغيرة و تحقيق الـذات

ومتغيرات الدراسـة.

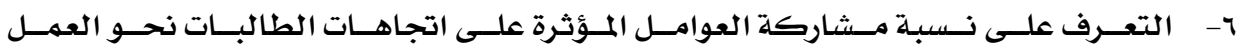

بالمشروعات الصغيرة

- - التعرف على نسبة مشاركة العوامل المؤثرة على تحقيق الذات .

فرضيات الدراسة

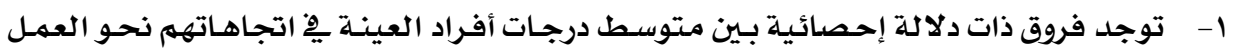

بالمشروعات الصغيرة تبعا لمتغيرات الدراسـة . 


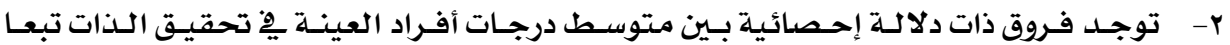

لمتغيرات الدراسـة

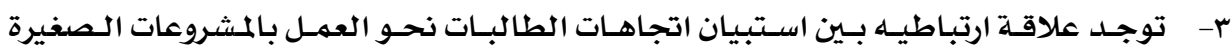

واستبـيان تحقيق الذات

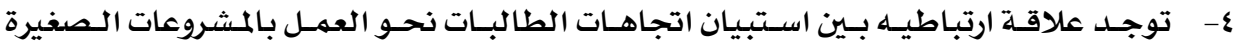

واستبيان تحقيق الذات ومتتغيرات الدراسة

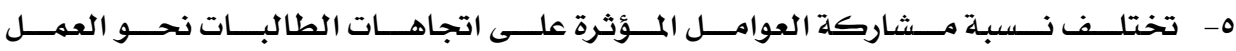

بالمشروعات الصغيرة

7- تختلف نسبة مشاركة العوامل المؤثرة على تحقيق الذات

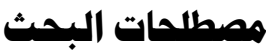

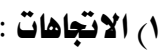

هناك عديد من الدراسـات التي تناولت الاتجـاهات وتطرقت لتعريفها :

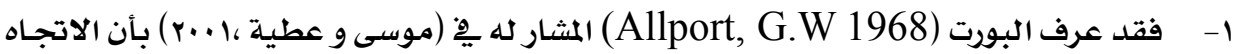

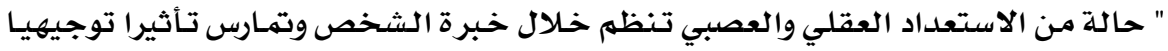

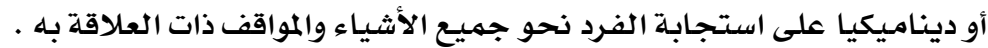

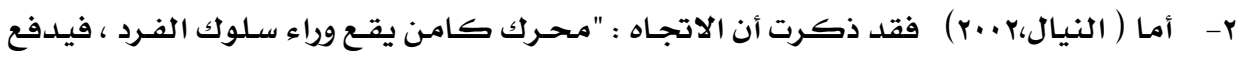

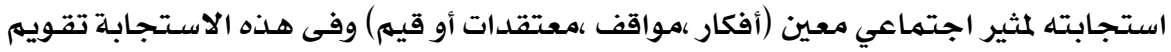

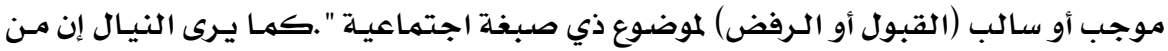

بين التعريفات الحديثة للاتجاه التعريف الذي وضعها سيد محمد عبد التبد العال

وتعرف الاتجاهات إجرائيا بأنها :

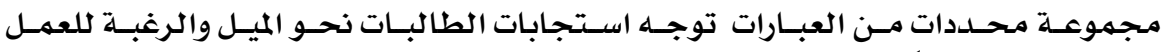

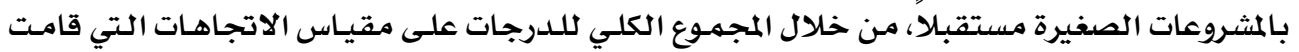
الباحثة ببنائه من خلال أداة الدراسة وهي الاستبانة من الماتل

r) المشروعات الصفيرة

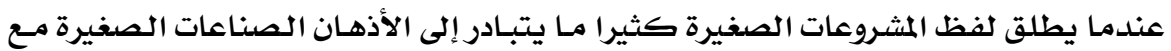

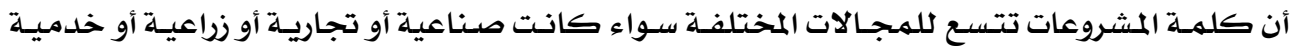

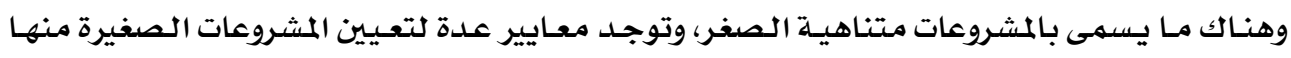

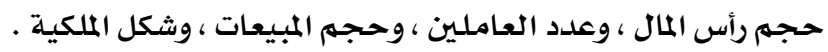

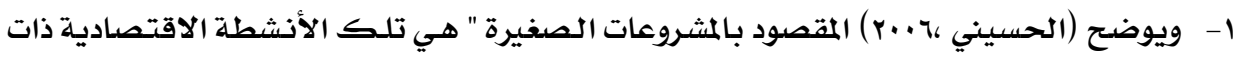

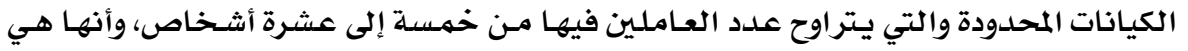

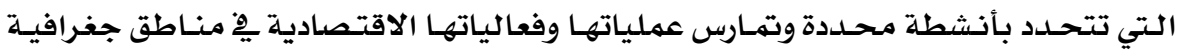




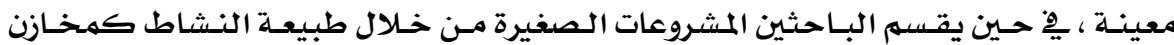

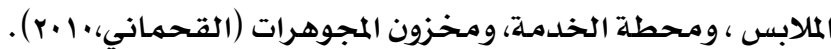

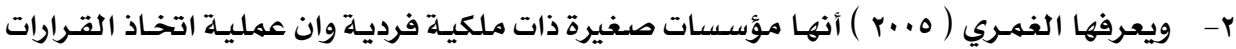

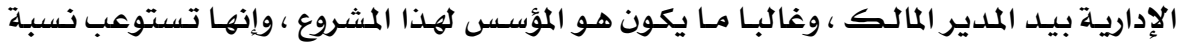

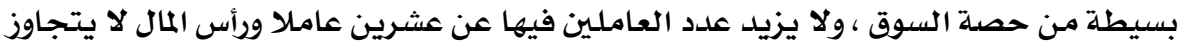

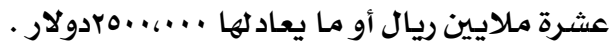
وتعرف المشروعات إجرائيا بأنها :

المشروعات التي تديرها المرأة وتكون صاحبه القرار فيها وتضهم عدد معين من العمال .

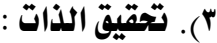

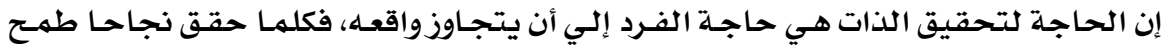

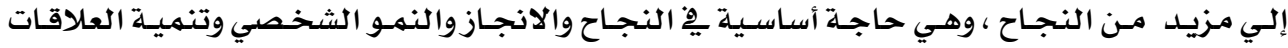

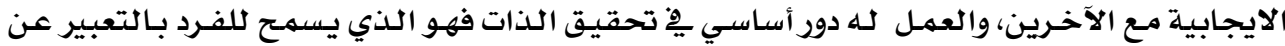

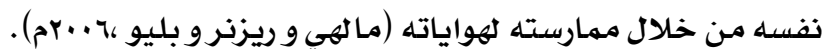

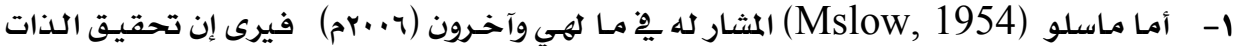

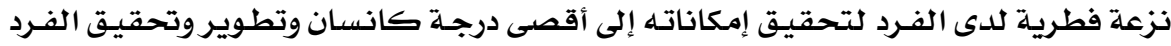

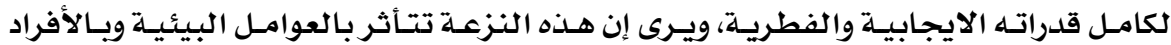

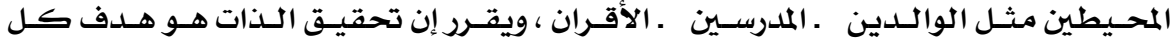

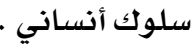

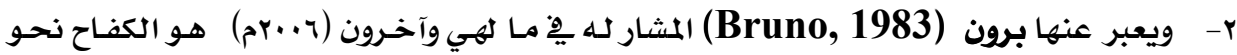
الكمال وتحقيق إمكانيات الفرد الفطرية والايجابية . ويعرف تحقيق الذات إجرائيا بأنه:

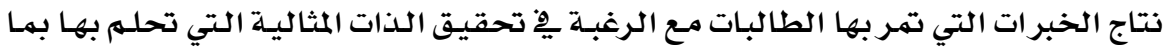

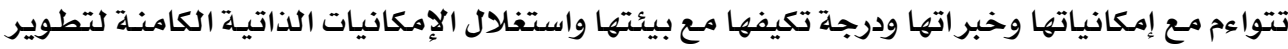

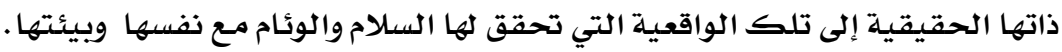

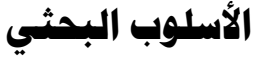

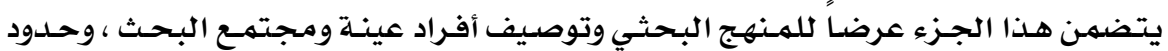
البـحث بالإضـافة إلى أسلوب جمـع البيانات وخطوات بناء أداة البحث والإجـراءات السكومتريـة للتقنـين من الصدق وثبات الاستبـانة وعرض إجراءوات تطبيق البهر البحث. ( ) منهج البحثث : يتبع هذا البحث المنهج الوصفي التحليلي ، وهو يشمل يِّ كثير مـن الأحيـان على عمليـات

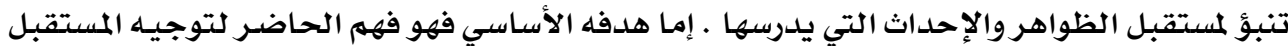


وذلك من خلال وصف الحاضـر بتـوفير بيانـات كافيـه لتوضـيحـه وفهمهـ ثم إجـراء المقارنات وتحديــ

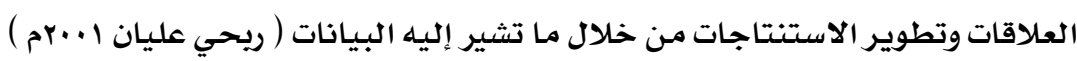

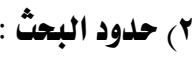

تتمثل حلدود البحث فيما يلي :-

اقتصـرت مـوضـوعات الدراســة علسى اتجـاهـات طالبـات الاقتــــاد المنزلـي نحـو العمـل بمجــال

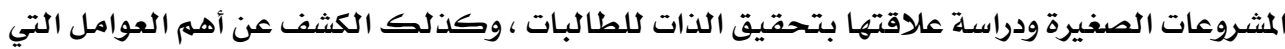

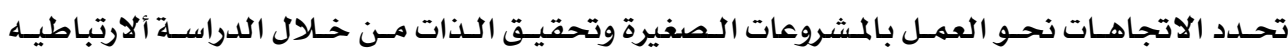

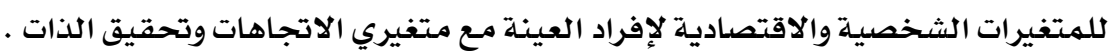

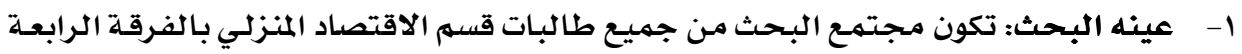

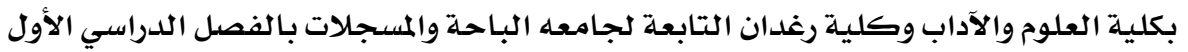

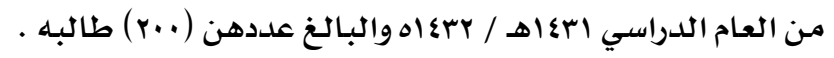

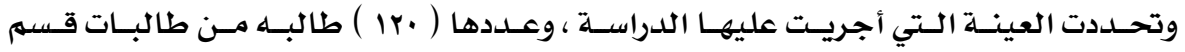

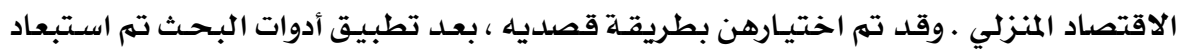

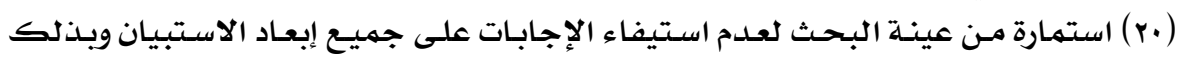

$$
\text { بلغت عينة البحث الكلي (. (.1) طالبهـ . }
$$

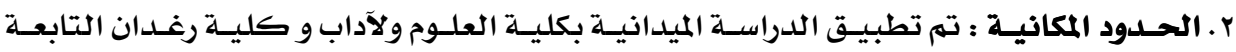

لجامعة الباحة

r. الحدود الزمانية: تم توزيع الاستمارات وجمعها خلال شهر محرم لعام بـعاهـ

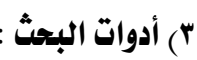

1- استمارة البيانات العامـة عن الطالبـة تشهل متتغيرات البـحث من ( إعداد الباحثة )

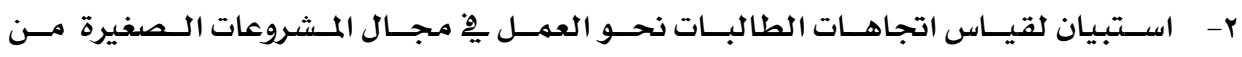

( إعداد الباحثة )

r- استبيان لقياس تحقيق الذات مـن ( إعداد الباحثة ) الباحثة )

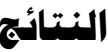

الثرض الأول :

توجد فروق ذات دلالة إحصدائية بـين متوسط درجـات أفراد العينـة يِّ اتجاهـاتهم نحو العمـل

بالمشروعات الصغيرة تبعا لمتغيرات الدراسـة

وللتحقـق مـن هـا الفـرض تم تطبيق اختبـار ( ت ) ، وحسـاب تحليـل التبـاين لـدرجات أفراد

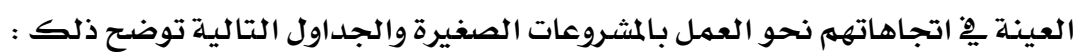




\begin{tabular}{|c|c|c|c|c|c|c|}
\hline الدلالة & قيمة & الحرية & | العينة & الانحراف & الحتوسط & عمر الطالبة \\
\hline \multirow{2}{*}{ دال عند ا+,• لصالح } & \multirow{2}{*}{16.387} & \multirow{2}{*}{94} & $0 \wedge$ & 23.545 & 89.534 & من •r سنة لأقل من ro سنة \\
\hline & & & $\xi r$ & 12.591 & 155.000 & من ب سنة فأكثر \\
\hline
\end{tabular}

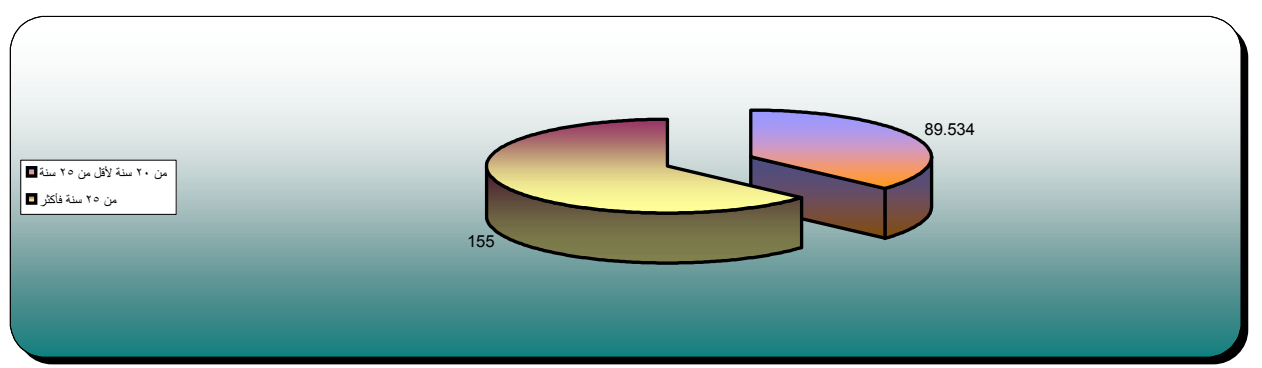

ثكل (1) الفروق ـ2 متوسط درجات أفراد العينة ـِ اتجاهاتهم نحو العمل بالمشروعات الصغيرة تبعا لمتغير العمر

يتـضح مـن الجـدول (1) وشـكل (1) أن قيهــة ( ت) كانـت (16.387) وهــى قيهــة داتـة

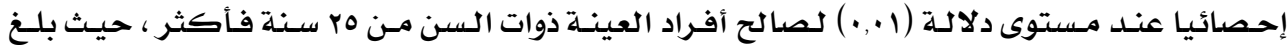

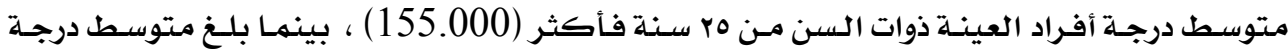

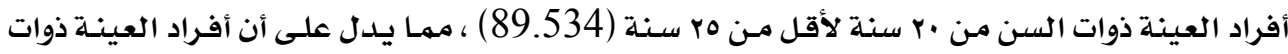
السن من ون سنـة فأكثر كانت اتجاهـاتهم نحو العمـل بالمشروعات الصغيرة أكبر مـن أفراد العينـة

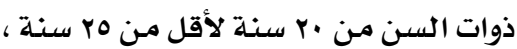

جدول (r) تحليل التباين لدرجات أفراد العينة يِ اتجاهاتهم نحو العمل بالمشروعات الصغيرة تبعا لمتغير تعليم الأب

\begin{tabular}{|c|c|c|c|c|c|}
\hline الدلالة & قيمة (ف) & درجات الحرية & متوسط المربعات & مجموع المربعات & تعليم الأب \\
\hline \multirow{2}{*}{ ا•,•• دال } & \multirow{2}{*}{63.914} & $r$ & 50208.125 & 100416.251 & بين المجموعات \\
\hline & & qr & 785.562 & 76199.532 & داخل المجموعات \\
\hline & & 99 & & IVITIO, VAT & المجموع \\
\hline
\end{tabular}

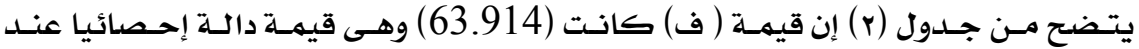

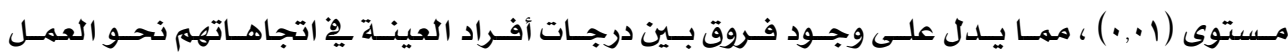
بالمشروعات الصغيرة تبعا لمتغير تعليه الأب ، ولمعرفة اتجاه الدلالة تم تطبيق اختبـار شيفيه للمقارنات

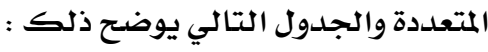


جدول (r) اختبار شيفيه للمقارنات المتعددة

\begin{tabular}{|c|c|c|c|}
\hline مالئ = 153.266 & مت = متوسط 101.575 & منغذض =م6090.09 & تعليه الأب \\
\hline & & - & منخفض \\
\hline & - & $* * 35.484$ & متوسط \\
\hline- & $* * 51.690$ & $* * 87.175$ & عالي \\
\hline
\end{tabular}

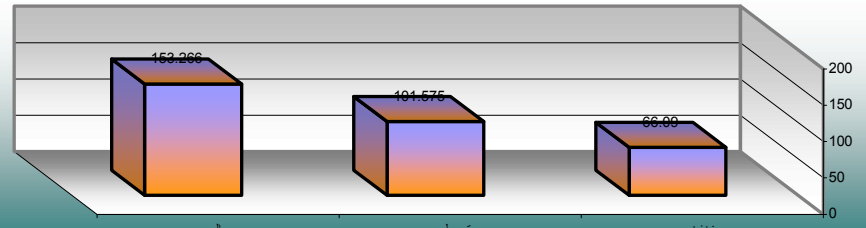

شكل ( ) فروق درجات أفراد العينة بِ اتجاهاتهم نحو العمل بالمشروعات الصغيرة تبعا لمتغير تعليم الأب

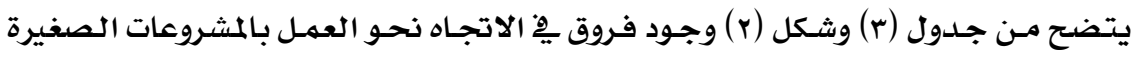

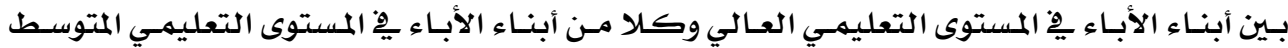

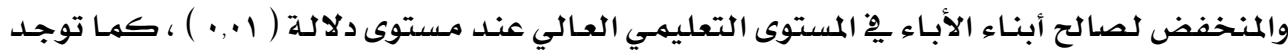

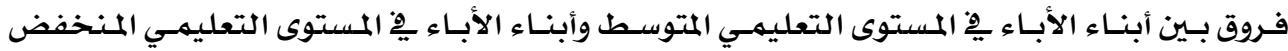

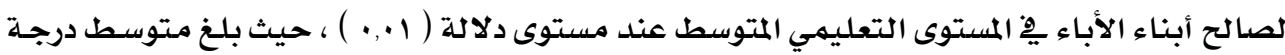

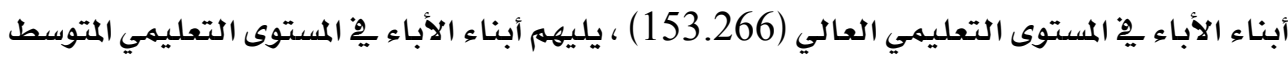

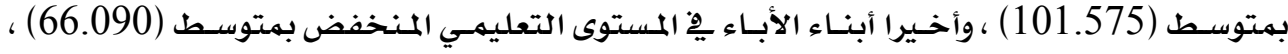

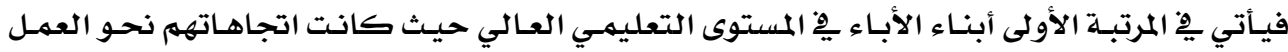

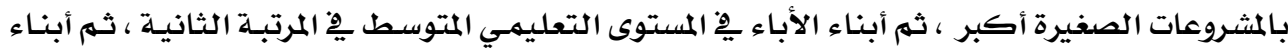

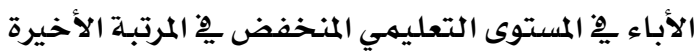

جدول (ع) تحليل التباين لدرجات أفراد العينة يـ اتجاهاتهم نحو العمل بالمشروعات الصغيرة تبعا لمتغير تعليم الأم

\begin{tabular}{|c|c|c|c|c|c|}
\hline الدلالة & قيمة (ف) & درجات الحرية & متوسط المربعات & مجموع المربعات & تعليم الأم \\
\hline \multirow{2}{*}{ اי,• دال } & \multirow{2}{*}{56.698} & $r$ & 49851.311 & 99702.622 & بين المجموعات \\
\hline & & qr & 879.236 & 85285.866 & داخل المجموعات \\
\hline & & 99 & & 184988.488 & المجموع \\
\hline
\end{tabular}

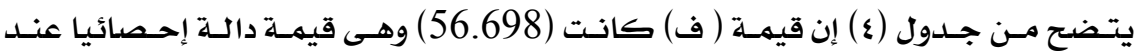

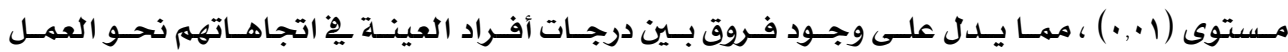


بالمشروعات الصغيرة تبعا لمتغير تعليه الأم ، ولمعرفة اتجاه الدلالـة تم تطبيق اختبـار شيفيه للمقارنات المتعددة والجدول التالي يوضح ذلك : بالك

جدول (ه) اختبار شيفيه للمقارنات المتعددة

\begin{tabular}{|c|c|c|c|}
\hline مالي =187.184 & متوسط = مت & منغفض = م8.615 & تعليم الأم \\
\hline & & - & منخفض \\
\hline & - & $* * 40.995$ & متوسط \\
\hline- & $* * 47.573$ & $* * 88.568$ & عالي \\
\hline
\end{tabular}

\section{(100)}

شكل (r) فروق درجات أفراد العينة يِ اتجاهاتهم نحو العمل بالمشروعات الصغيرة تبعا لتغير تعليم الأم

يتضـح مـن جـدول (0) وشـكل (r) وجـود فروق يِّ الاتجـاه نحـو العهـل بـالمشروعات الصغيرة

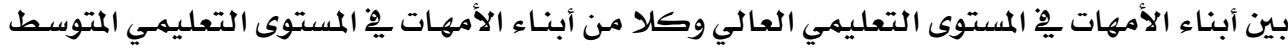

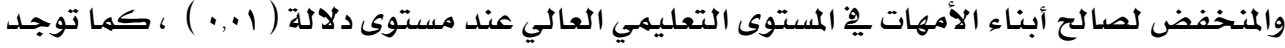

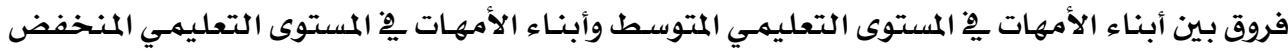

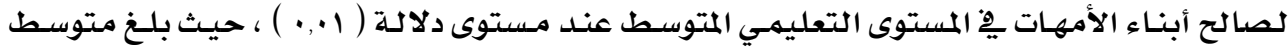

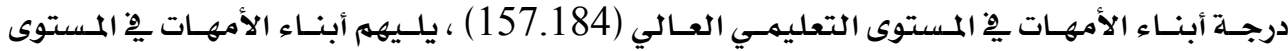

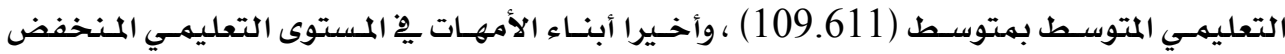

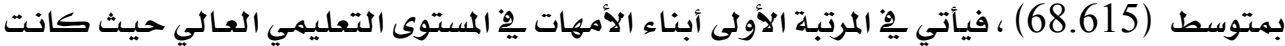

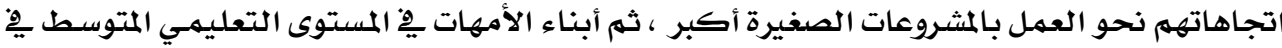

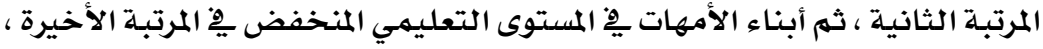

جدول (ף) تحليل التباين لدرجات أفراد العينة يو اتجاهاتهم نحو العمل بالمشروعات الصغيرة تبعا لمتغير مهنة الأب

\begin{tabular}{|c|c|c|c|c|c|}
\hline الدلالة & قيمة (ف) & درجات الحرية & متوسط المربعات & مجموع المربعات & مهنة الأب \\
\hline \multirow{2}{*}{ اי,• دال } & \multirow{2}{*}{51.050} & $r$ & 35679.210 & 107037.629 & بين المجموعات \\
\hline & & 97 & 698.901 & 67094.487 & داخل المجموعات \\
\hline & & 99 & & 174132.116 & المجموع \\
\hline
\end{tabular}

يتضح من جلدول (7) إن قيمة ( ف) كانت (51.050) وهى قيمة دالة إحصائيا عند مستوى

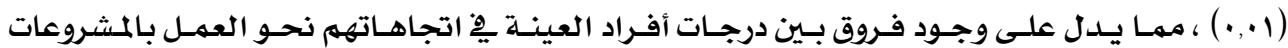


الصغيرة تبعـا لمتتغير مهنـة الأب ، ولمعرفـة اتجـاه الدلالـة تم تطبيـق اختبـار شـيفيه للمقارنـات المتعـددة والجدول التالي يوضسح ذلك :

جدول (v) اختبار شيفيه للمقارنات المتعددة

\begin{tabular}{|c|c|c|c|c|}
\hline م= لا يعمل & أعمال حرة =75.100 & وظيفة في قطاع خاص & وظيفة حكومية & مهنة الأب \\
\hline & & & - & وظيفة حكومية \\
\hline & & - & $* * 56.015$ & وظيفة في قطاع خاص \\
\hline & - & $* 8.460$ & $* * 64.475$ & أعمال حرة \\
\hline- & $* * 93.500$ & $* * 85.040$ & $* * 29.025$ & لا يعمل \\
\hline
\end{tabular}

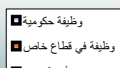

$$
\begin{aligned}
& \text { 口أ }
\end{aligned}
$$

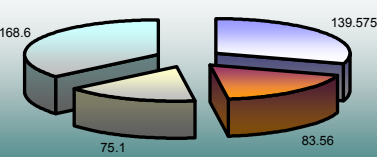

شكل (ع) فروق درجات أفراد العينة ـِ اتجاهاتهم نحو العمل بالمشروعات الصغيرة تبعا لمتغير مهنة الأب

يتضح من جدول (v) وشكل (ع) وجود فروق يِ الاتجـاه نحو العمل بالمشروعات الصغيرة بـين

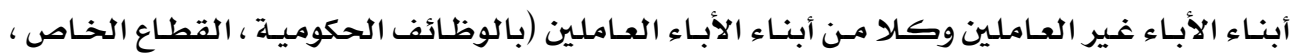

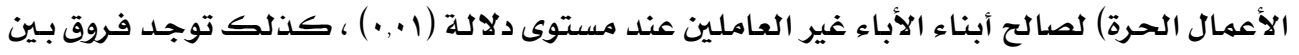

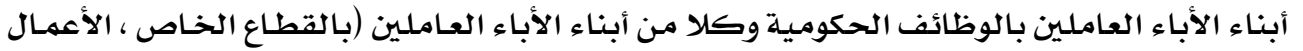

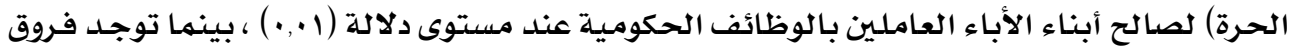

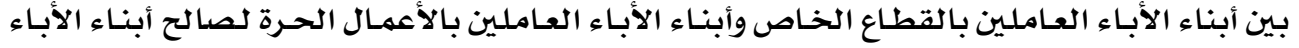
العاملين بالقطاع الخاص عند مستوى دلالة (0. (. ) ) ، حيث بلغ متوسط درجـة أبناء الأباء غير العاملين

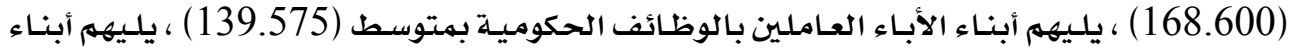
الأباء العـاملين بالقطاع الخـاص بهتوسط (83.560) ، وأخـيرا أبنـاء الأبـاء العـاملين بالأعمـال الحـرة

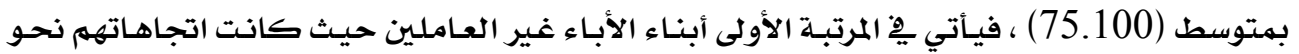

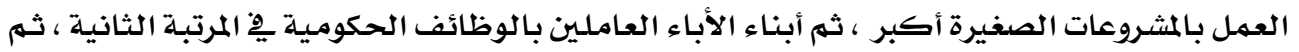

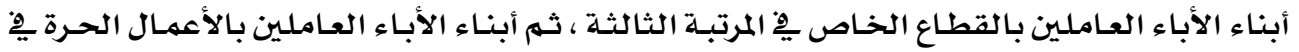




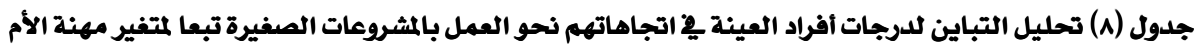

\begin{tabular}{|c|c|c|c|c|c|}
\hline الدلالة & قيمة (ف) & درجات الحرية & متوسط المربعات & مجموع المربعات & مهنة الأم \\
\hline \multirow{2}{*}{ וי,•• داJ } & \multirow{2}{*}{53.128} & $r$ & 36995.246 & 110985.738 & بين المججموعات \\
\hline & & 97 & 696.344 & 66849.006 & داخل المجموعات \\
\hline & & 99 & & 177834.744 & المجموع \\
\hline
\end{tabular}

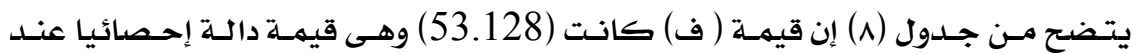

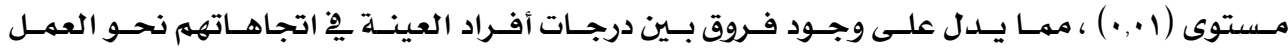
بـالمشروعات الصغيرة تبعا لمتغير مهنـة الأم ، ولمعرفة اتجـاه الدلادة تم تطبيـق اختبـار شـيفيه للمقارنات المتعددة والجدول التالي يوضح ذلك :

جدول (9) اختبار شيفيه للمقارنات المتعددة

\begin{tabular}{|c|c|c|c|c|}
\hline م= 163.269 تعمل & أعمال حرة & وظيفة في قطاع خاص & وظيفة حكومية & مهنة الأم \\
\hline & & & - & وظيفة حكومية \\
\hline & & - & $* * 52.674$ & وظيفة في قطاع خاص \\
\hline & - & 2.420 & $* * 55.094$ & أعمال حرة \\
\hline- & $* * 89.975$ & $* * 87.554$ & $* * 34.880$ & لا تعمل \\
\hline
\end{tabular}

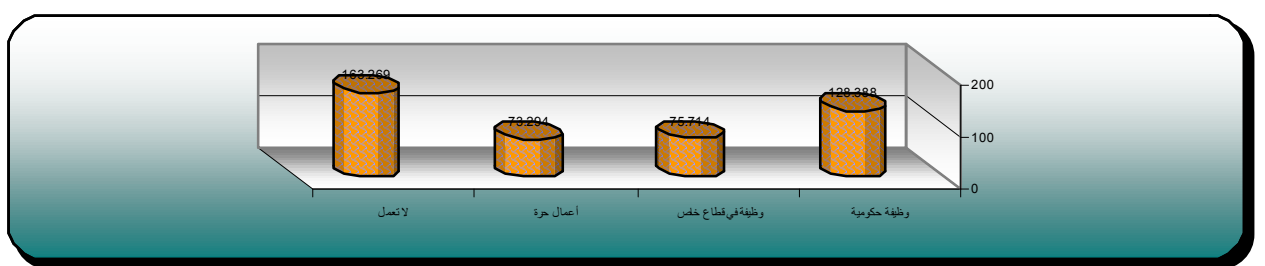

شكل ( 0 ) فروق درجات أفراد العينة ِِِ اتجاهاتهم نحو العمل بالمشروعات الصغيرة تبعا لمتفير مهنة الأم

يتضح مـن جدول (و) وشكل (0) وجود فروق يخ الاتجاه نحو العمـل بـالمشروعات الصغيرة بـين أبناء الأمهات غير العاملات وكلا من أبناء الأمهات العاملات (بالوظائف الحكومية ، القطاع الخاص ، الأعمال الحـرة) لصسالح أبناء الأمهات غير العـامـلات عند مسستوى دلالـة (1 . • ) ، كهـا توجـد فروق بـين أبنـاء الأمهـات العـامـلات بالوظـائف الحكوميـة وكـلا مـن أبنـاء الأمهات العـامـلات (بالقطـاع الخـاص ،

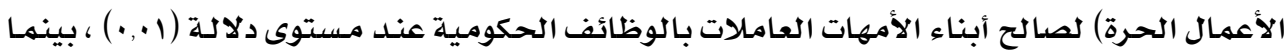
لا توجد فروق بين أبناء الأمهات العامـلات بالقطاع الخاص وأبناء الأمهات العـامـالات بالأعمـال الحـرة ،

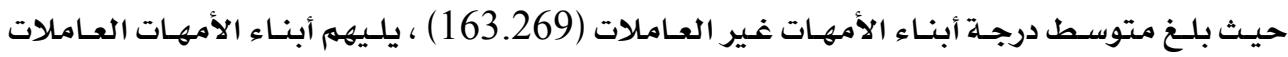

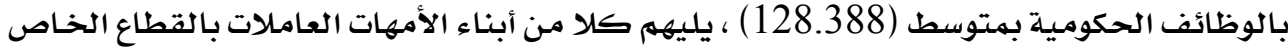
وأبناء الأمهات العـامـلات بـالأعمـال الحـرة بهتوسطين علي التوالي (75.714) ، (73.294) ، فيـأتي يْ 
المرتبـة الأولى أبنـاء الأمهات غير العـاملات حيـث كانت اتجـاهـاتهم نحـو العمل بالمشروعات الصغيرة

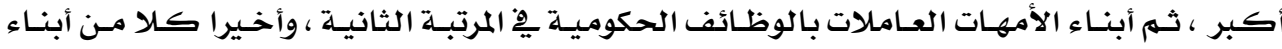

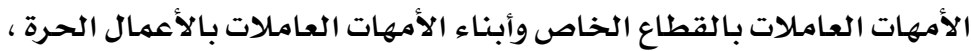

جدول (ـ ا ) تحليل التباين لدرجات أفراد العينة فِ اتجاهاتهم نحو العمل بالشروعات الصغيرة تبعا لمتغير عدد أفراد الأسرة

\begin{tabular}{|c|c|c|c|c|c|}
\hline الدلالة & قيمة (ف) & درجات الحرية & متوسط المربعات & مجموع المربعات & عدد أفراد الأسرة \\
\hline \multirow{2}{*}{ اי,•• دال } & \multirow{2}{*}{63.199} & $r$ & 49387.656 & 98775.312 & بين المجموعات \\
\hline & & 9v & 781.463 & 75801.870 & داخل المجموعات \\
\hline & & 99 & & 174577.182 & المجموع \\
\hline
\end{tabular}

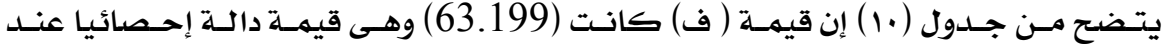

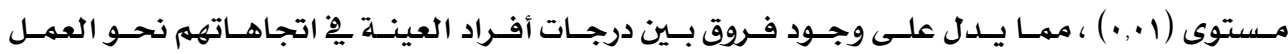

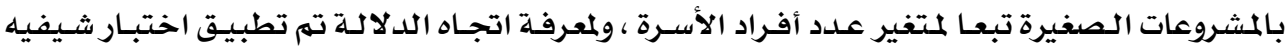

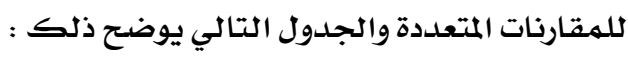
جدول (11) اختبار شيفيه للمقارنات المتعددة

\begin{tabular}{|c|c|c|c|}
\hline من ^ أفراد فأكثر م= & من ه إلب لى أفراد & من r إلي ع أفراد & عدد أفراد الأسرة \\
\hline & & - & من ץ إلي ع أفراد \\
\hline & - & $* * 41.848$ & من ه إلي v أفراد \\
\hline - & $* * 47.623$ & $* * 89.472$ & من ^ أفراد قأكثر \\
\hline
\end{tabular}

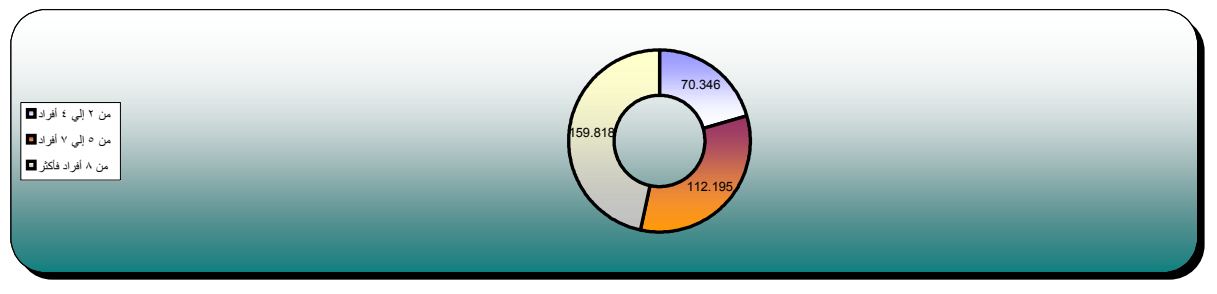

شكل (ף) فروق درجات أفراد العينة يِّ اتجاهاتهم نحو العمل بالمشروعات الصغيرة تبعا لمتغير عدد أفراد الأسرة يتضـح من جدول (11) وشكل (7) وجـود فروق يِّ الاتجـاه نحو العهـل بالمشروعات الصغيرة

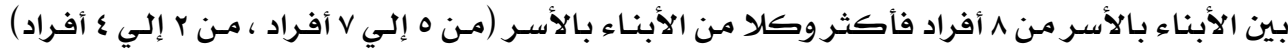

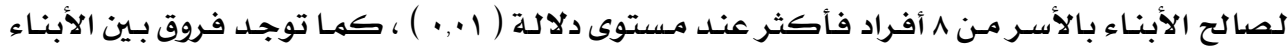

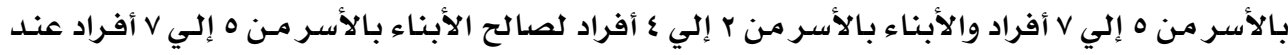

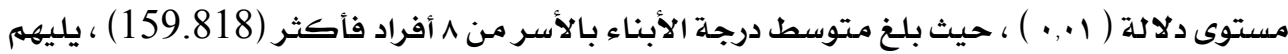

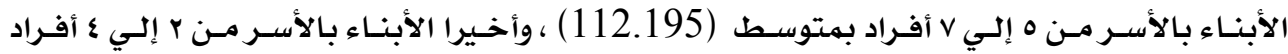




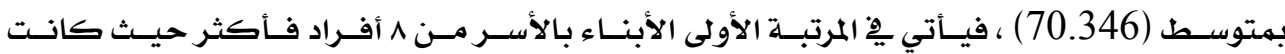

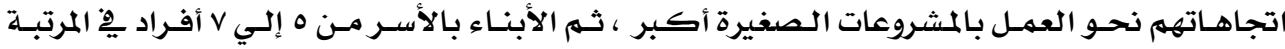

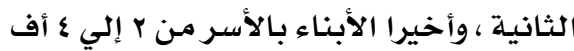

جدول (r) ) تحليل التباين لدرجات أفراد العينة فِ اتجاهاتهم

نحو العمل بالمشروعات الصغيرة تبعا لمتفير الدخل الشهري للأسرة

\begin{tabular}{|c|c|c|c|c|c|}
\hline الدلالة & قيمة ( ف) & درجات الحرية & متوسط المربعات & مجموع المربعات & الدخل الشهري للأسرة \\
\hline \multirow{2}{*}{ גון, } & \multirow{2}{*}{48.469} & r & 35613.819 & 71227.638 & بين المجموعات \\
\hline & & $9 V$ & 734.776 & 71273.272 & داخل المجموعات \\
\hline & & 99 & & 142500.910 & المجموع \\
\hline
\end{tabular}

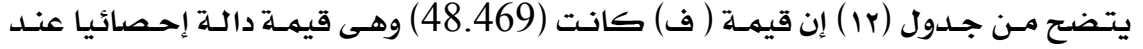

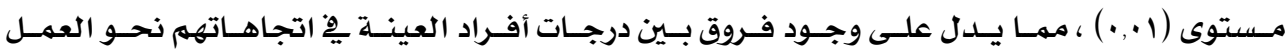

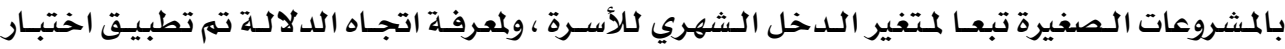

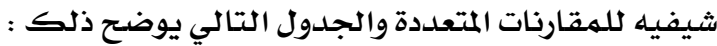
جدول (rا ) اختبار شيفيه للمقارنات المتعددة

\begin{tabular}{|c|c|c|c|}
\hline مرتفع & مترسط =م 129.065 & منغ = منفض & الدخل الشهري للأسرة \\
\hline & & - & منخفض \\
\hline & - & 4.055 & متوسط \\
\hline - & $* * 63.684$ & $* * 67.740$ & مرتفع \\
\hline
\end{tabular}

شكل (v) فروق درجات أفراد العينة فِ اتجاهاتهم

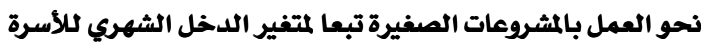

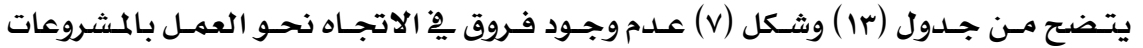

الصغيرة بين الأبناء بالأسـر ذوي الدخل المنخفض والأبناء بالأسـر ذوي الدخل المتوسط ، بينهـا توجـد

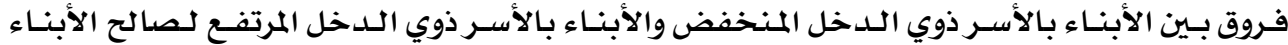

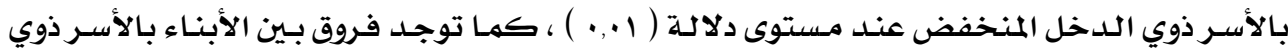

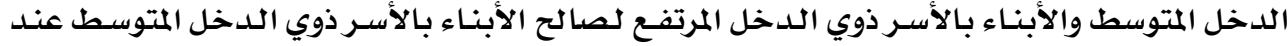

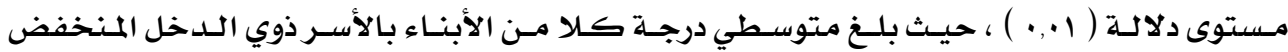




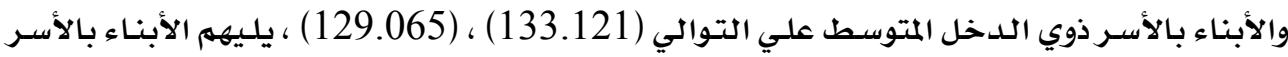

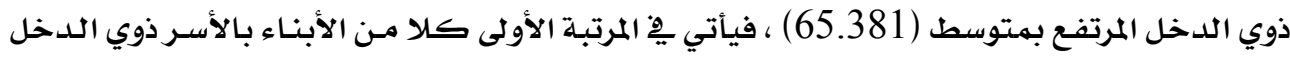

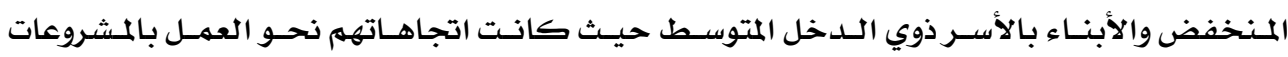

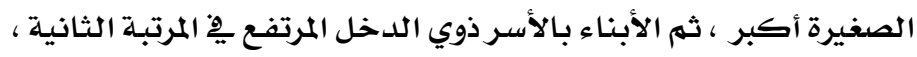

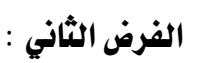

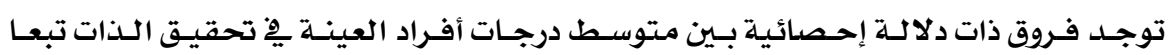

$$
\text { لمتغيرات الدراسة توجلة فورة }
$$

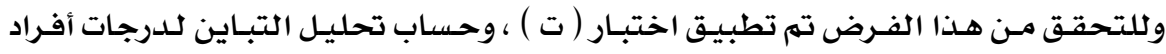

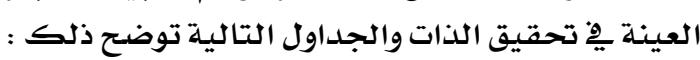

جدول (\& ) الفروق بِّ متوسط درجات أفراد العينة يِ تحقيق الذات تبعا لمتغير العمر

\begin{tabular}{|c|c|c|c|c|c|c|}
\hline الدلالة & قيمة & الحرجية & العينة & الانحراف & المتوسط الحسبي & عمر الطالبة \\
\hline \multirow{2}{*}{ دال عند ا+, • لصالح } & 14.5 & \multirow{2}{*}{$9 \Lambda$} & $\Delta \Lambda$ & 9.946 & 47.275 & من •r سنة لأقل من ro سنة \\
\hline & 21 & & $\xi r$ & 8.278 & 74.595 & من ro سنة قأكثر \\
\hline
\end{tabular}

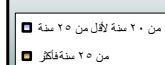

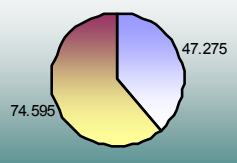

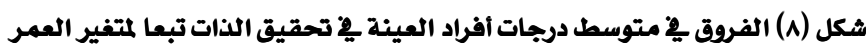

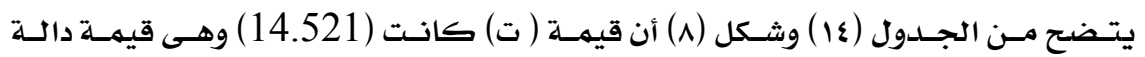

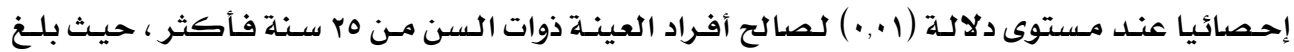

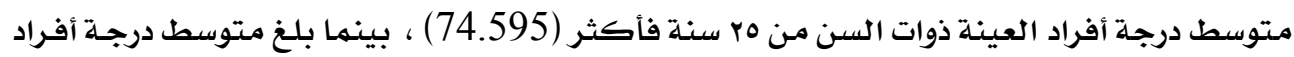

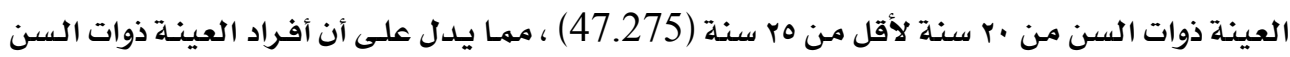

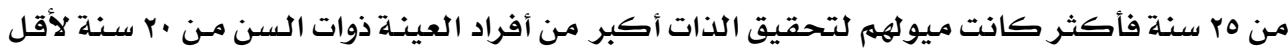

\begin{tabular}{|c|c|c|c|c|c|}
\hline الدلالة & قيمة (ف) & درجات الحرية & متوسط المربعات & مجموع المربعات & تعليم الأب \\
\hline \multirow{3}{*}{ ו•,• داJ } & \multirow{2}{*}{66.529} & $r$ & 7701.199 & 15402.398 & بين المجموعات \\
\hline & & 9v & 115.756 & 11228.352 & داخل المجموعات \\
\hline & & 99 & & 26630.750 & المجموع \\
\hline
\end{tabular}
من مب سنة ro 


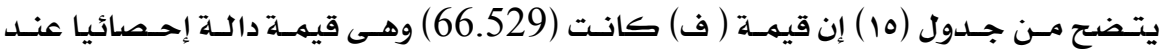

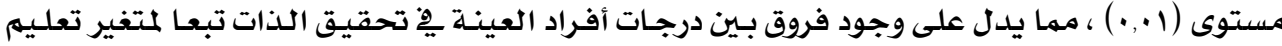

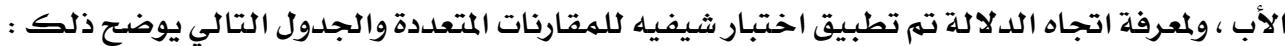
جدول (1 ) اختبار شيفيه للمقارنات المتعددة

\begin{tabular}{|c|c|c|c|}
\hline م= عالي = & متوسط = مت & منغ =م & تعليم الأب \\
\hline & & - & منخفض \\
\hline & - & $* * 26.242$ & متوسط \\
\hline - & $* 5.472$ & $* * 31.715$ & عالي \\
\hline
\end{tabular}

شكل (9) فروق درجات أفراد العينة بِ تحقيق الذات تبعا لمتغير تعليم الأب

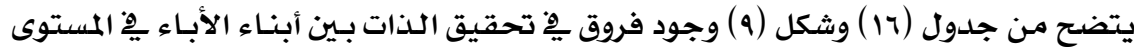

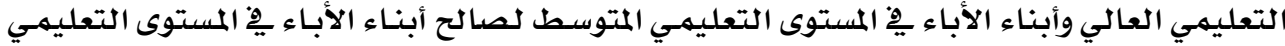

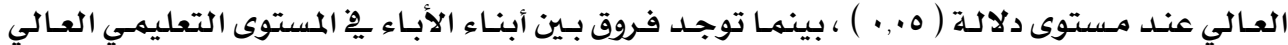

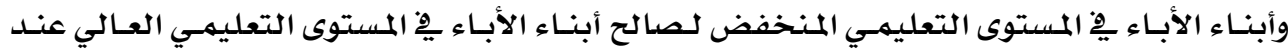

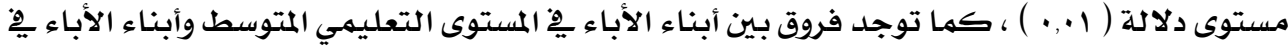

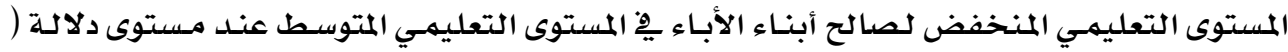

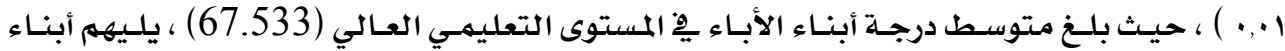

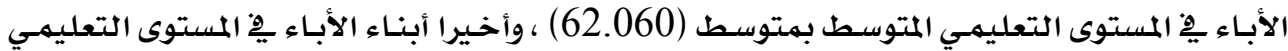

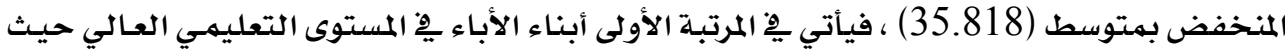

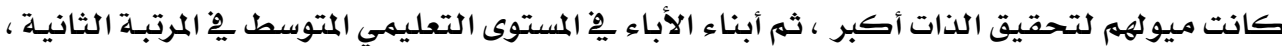

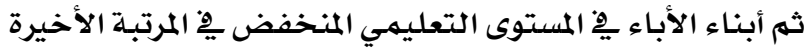

جدول (IV) تحليل التباين لدرجات أفراد العينة يِّ تحقيق الذات تبعا لمتغير تعليم الأم

\begin{tabular}{|c|c|c|c|c|c|}
\hline الدلالة & قيمة (ف) & درجات الحرية & متوسط المربعات & مجموع المربعات & تعليم الأم \\
\hline \multirow{3}{*}{ ו•,• دال } & \multirow{2}{*}{49.492} & $r$ & 9179.446 & 18358.893 & بين المجموعات \\
\hline & & 9r & 185.472 & 17990.747 & داخل المجموعات \\
\hline & & 99 & & 36349.640 & المجموع \\
\hline
\end{tabular}




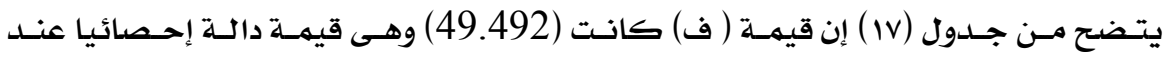

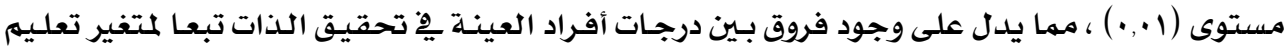

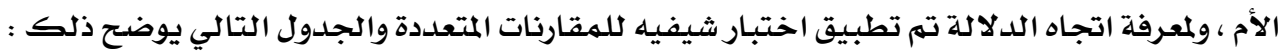
جدول (1) اختبار شيفيه للمقارنات المتعددة

\begin{tabular}{|c|c|c|c|}
\hline ه = عالي 75.973 & م= متوسط & 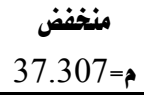 & تعليم الأم \\
\hline & & - & منغفض \\
\hline & - & $* * 18.747$ & متوسط \\
\hline- & **19.918 & $* * 38.665$ & عائي \\
\hline
\end{tabular}

شكل (. ا) فروق درجات أفراد العينة يِ تحقيق الذات تبعا لمتغير تعليم الأم

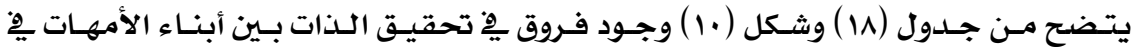

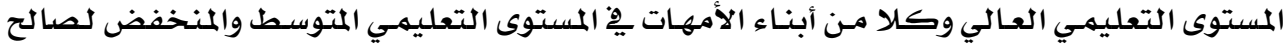

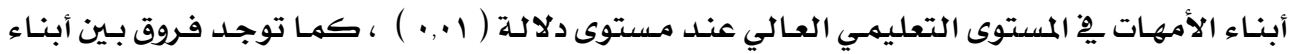

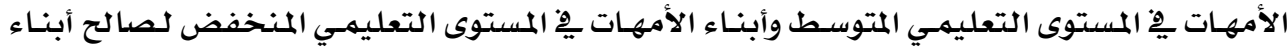

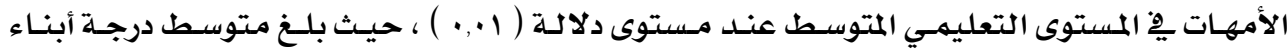

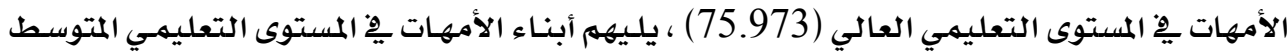

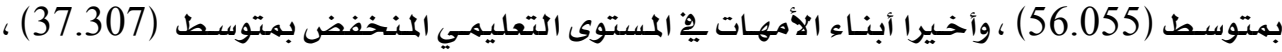

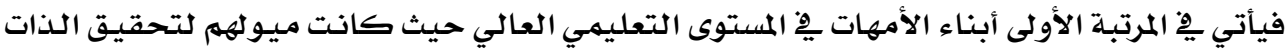

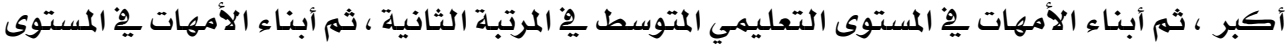
التعليمي المنخفض فِ إنمرتبة الأخيرة

جدول (19) تحليل التباين لدرجات أفراد العينة بِ تحقيق الذات تبعا لمتفير مهنة الأب

\begin{tabular}{|c|c|c|c|c|c|}
\hline الدلالة & قيمة (ف) & درجات الحرية & متوسط المربعات & مجموع المربعات & مهنة الأب \\
\hline \multirow{2}{*}{ 1, 1, دال } & \multirow{2}{*}{56.787} & $r$ & 6458.351 & 19375.052 & بين المجموعات \\
\hline & & 97 & 113.729 & 10917.948 & داخل المجموعات \\
\hline & & 99 & & 30293.000 & المجموع \\
\hline
\end{tabular}




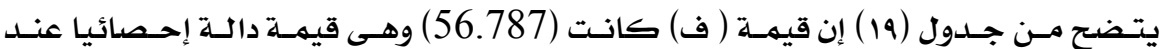

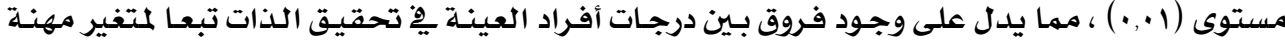

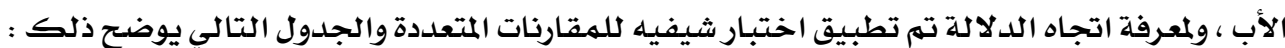

جدول ( • ) ) اختبار شيفيه للمقارنات المتعددة

\begin{tabular}{|c|c|c|c|c|}
\hline $\begin{array}{c}\text { ل يعمل = } \\
33.533\end{array}$ & 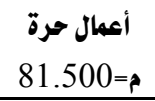 & وظيفة في قطاع خاص & وظيفة حكومية & مهنة الأب \\
\hline & & & - & وظيفة حكومية \\
\hline & & - & $* * 15.455$ & وظيفة في قطاع خاص \\
\hline & - & $* * 14.420$ & $* * 29.875$ & أعمال حرة \\
\hline- & $* * 47.966$ & $* * 33.546$ & $* * 18.091$ & لا يعمل \\
\hline
\end{tabular}

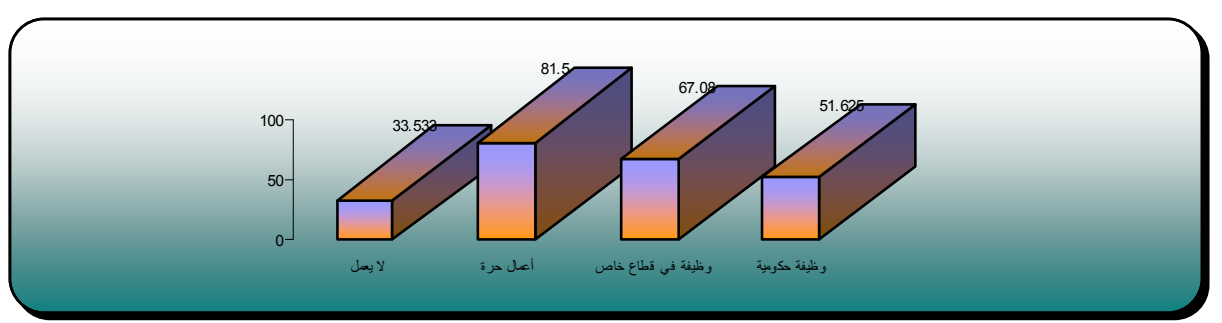

شكل (11) فروق درجات أفراد العينة ف2 تحقيق الذات تبعا لمتفير مهنة الأب

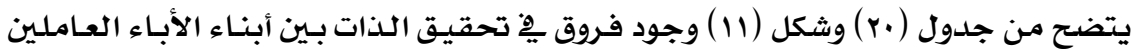

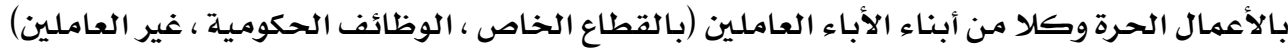

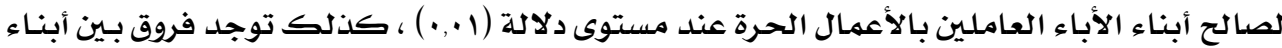

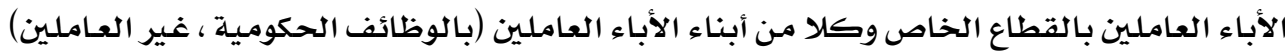

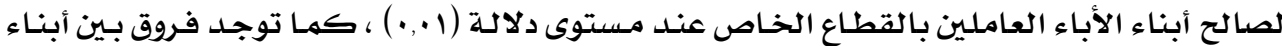

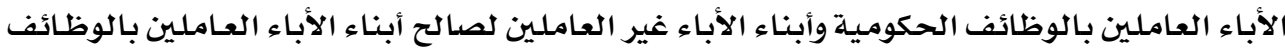

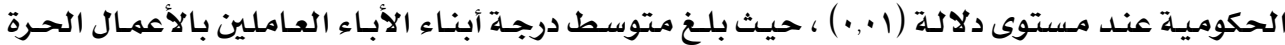

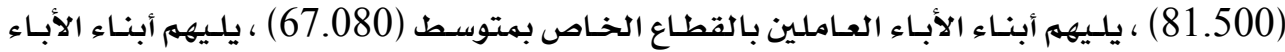

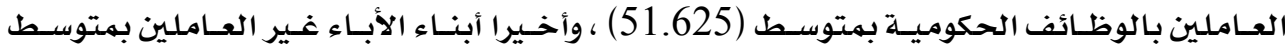

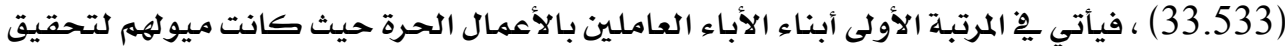

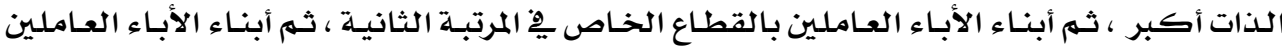

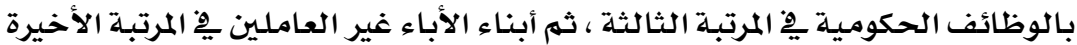


جدول ( r ) ) تحليل التباين لدرجات أفراد العينة يِ تحقيق الذات تبعا لمتغير مهنة الأم

\begin{tabular}{|c|c|c|c|c|c|}
\hline الدلالة & قيمة (ف) & درجات الحرية & متوسط المربعات & مجموع المربعات & مهنة الأم \\
\hline \multirow{2}{*}{ 1.,• دال } & \multirow{2}{*}{56.688} & $r$ & 6200.815 & 18602.444 & بين المجموعات \\
\hline & & 97 & 109.384 & 10500.866 & داخل المجموعات \\
\hline & & 99 & & 29103.310 & المجموع \\
\hline
\end{tabular}

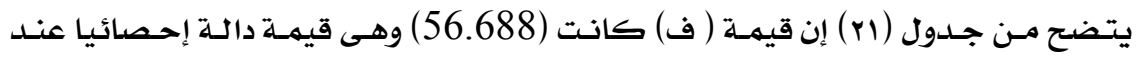

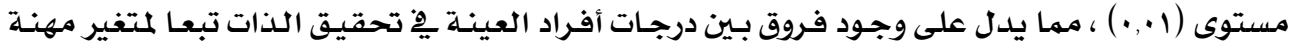

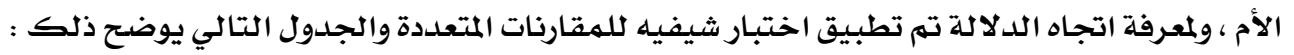

جدول (rr) اختبار شيفيه للمقارنات المتعددة

\begin{tabular}{|c|c|c|c|c|}
\hline $\begin{array}{c}\text { ل تعمل = } 38.615 \\
\end{array}$ & أعمال حرة & وظيفة في قطاع خاص & وظيفة حكومية & مهنة الأم \\
\hline & & & - & وظيفة حكومية \\
\hline & & - & $* 4.591$ & وظيفة في قطاع خاص \\
\hline & - & $* * 19.322$ & $* * 23.913$ & أعمال حرة \\
\hline- & $* * 44.325$ & $* * 25.003$ & $* * 20.412$ & لا تعمل \\
\hline
\end{tabular}

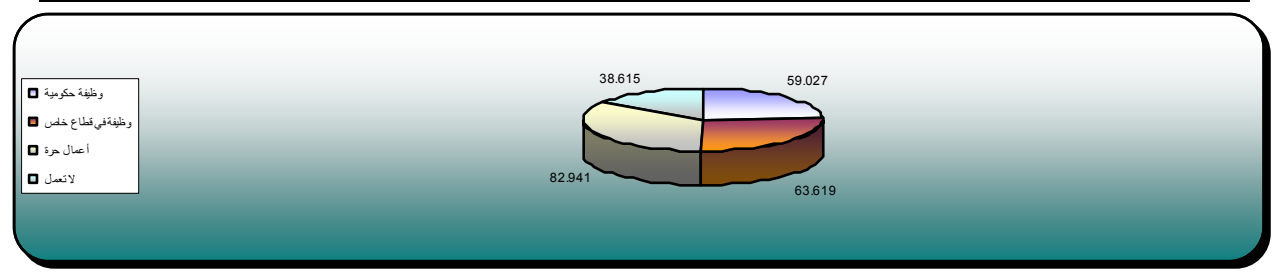

شكل (r) فروق درجات أفراد العينة يِّ تحقيق الذات تبعا لمتغير مهنة الأم

يتضح من جدول (rr) وشكل (r) ) وجود فروق يِ تحقيق الذات بين أبناء الأمهات العاملات

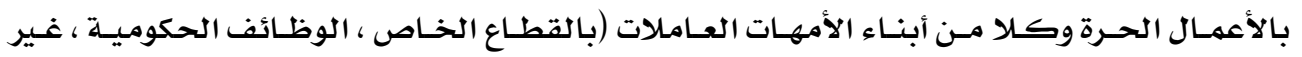

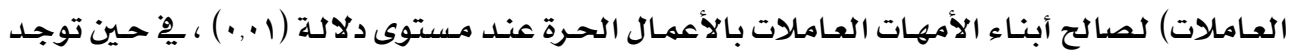

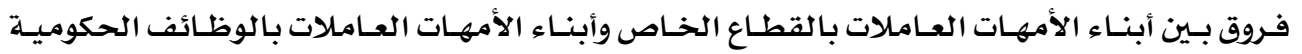

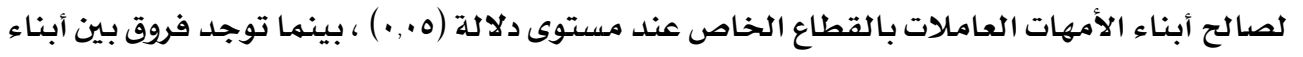

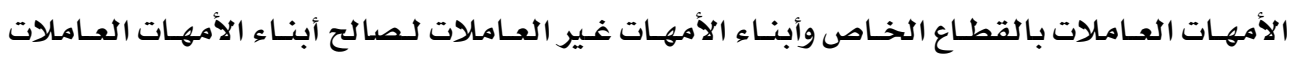

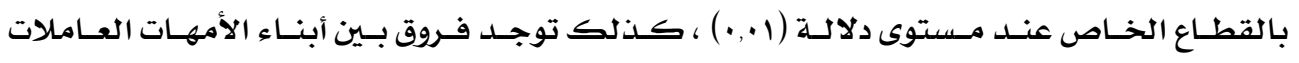

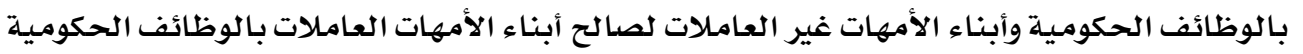

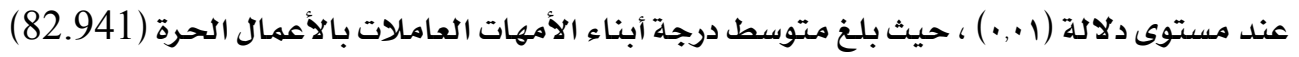

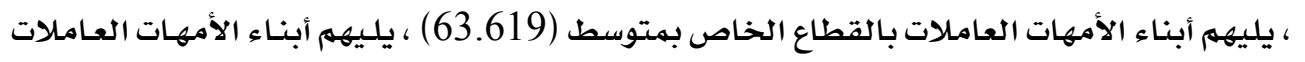


بالوظائف الحكومية بهتوسط (59.027) ، وأخيرا أبناء الأمهات غير العاملات بمتوسط (38.615) ،

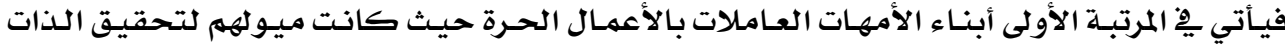

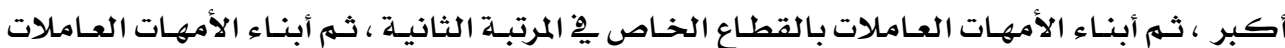

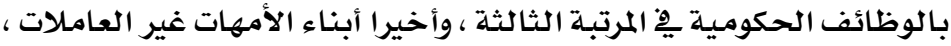

جدول (rr) تحليل التباين لدرجات أفراد العينة يْ تحقيق الذات تبعا لمتفير عدد أفراد الأسرة

\begin{tabular}{|c|c|c|c|c|c|}
\hline الدلالة & قيمة (ف) & درجات الحرية & متوسط المربعات & مجموع المربعات & علد أفراد الأسرة \\
\hline \multirow{2}{*}{ ו•,• دال } & \multirow{2}{*}{47.088} & $r$ & 6917.205 & 13834.410 & بين المجموعات \\
\hline & & $9 v$ & 146.900 & 14249.338 & داخل المجموعات \\
\hline & & 99 & & $r \wedge \cdot \wedge r, V \leqslant \Lambda$ & المجموع \\
\hline
\end{tabular}

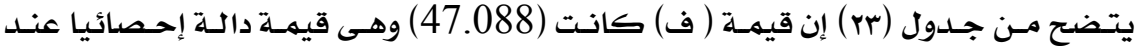

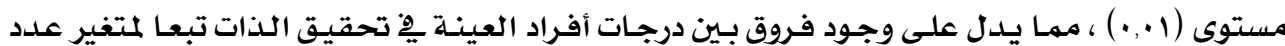

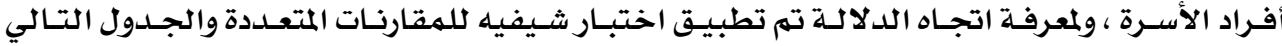
يوضح ذلك :

جدول (؟) اختبار شيفيه للمقارنات المتعددة

\begin{tabular}{|c|c|c|c|}
\hline من ^ أفراد فأكثر م= 48.393 & من ه إلي v أفراد & من ץ إلي ع أفراد & عدد أفراد الأسرة \\
\hline & & - & من r إلي ₹ أفراد \\
\hline & - & $* * 25.070$ & من ه إلي V أفراد \\
\hline- & *5.728 & $* * 30.798$ & من ^ أفراد فأكثر \\
\hline
\end{tabular}

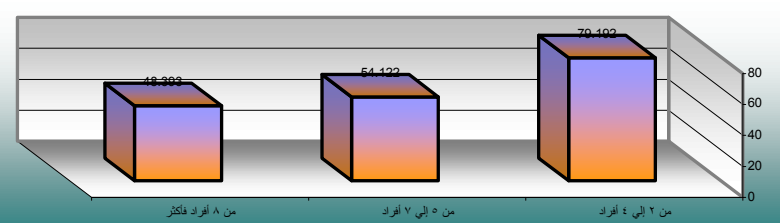

شكل (r) فروق درجات أفراد العينة فِ تحقيق الذات تبعا لمتغير عدد أفراد الأسرة

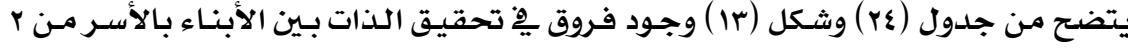

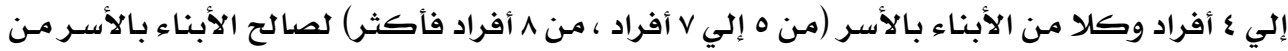

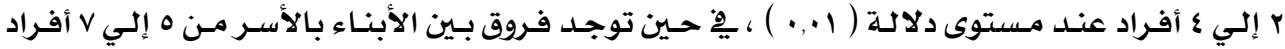

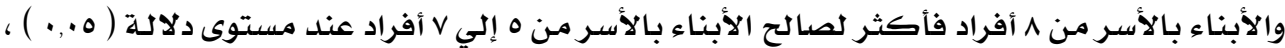

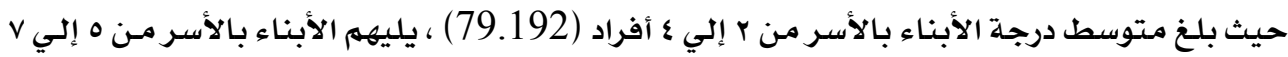


أفراد بمتوسط (54.122) ، وأخيرا الأبناء بالأسر من ^ أفراد فأكثر بمتوسط (48.393) ، فيأتي هِ

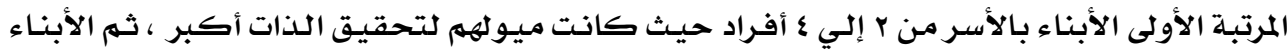

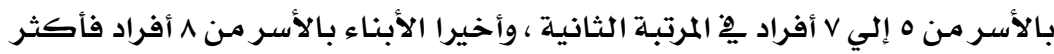
جدول (ro) تحليل التباين لدرجات أفراد العينة ـِ تحقيق الذات تبعا لمتغير الدخل الشهري للأسرة

\begin{tabular}{|c|c|c|c|c|c|}
\hline الدلالة & قيمة (ف) & درجات الحرية & متوسط المربعات & مجموع المربعات & الدخل الشهري للأسرة \\
\hline \multirow{2}{*}{ اי,• داJ } & \multirow{2}{*}{45.057} & r & 8767.775 & 17535.551 & بين المجموعات \\
\hline & & qr & 194.591 & 18875.343 & داخل المجموعات \\
\hline & & 99 & & 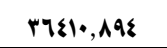 & المجموع \\
\hline
\end{tabular}

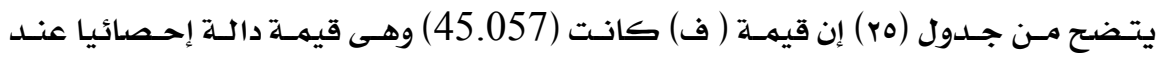

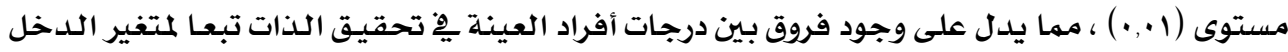

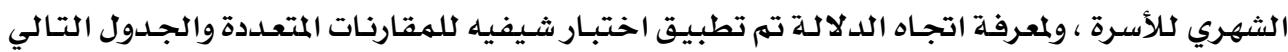
يوضح ذلك : جدول (ro) اختبار شيفيه للمقارنات المتعددة

\begin{tabular}{|c|c|c|c|}
\hline مرتفع = & متوسط = مت & 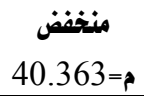 & اللدخل الشهري للأسرة \\
\hline & & - & منخفض \\
\hline & - & $* * 21.397$ & متوسط \\
\hline- & $* * 19.286$ & $* * 40.683$ & مرتفع \\
\hline
\end{tabular}

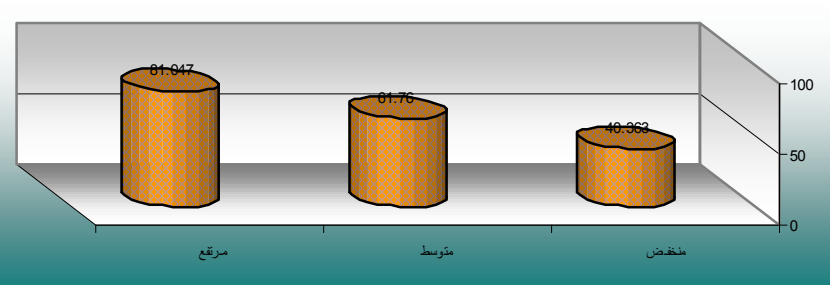

شكل (\& ) فروق درجات أفراد العينة يف تحقيق الذات تبعا لمتفير الدخل الشهري للأسرة

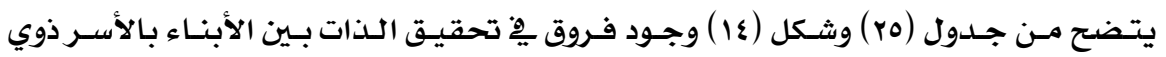

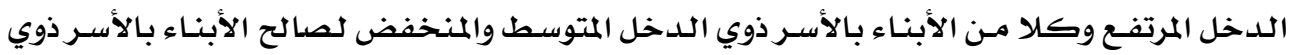

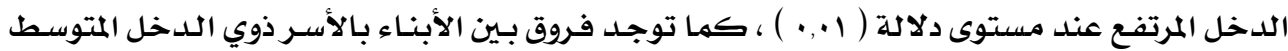

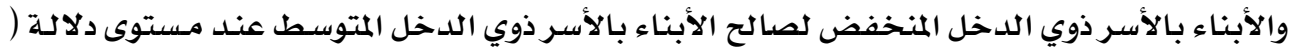

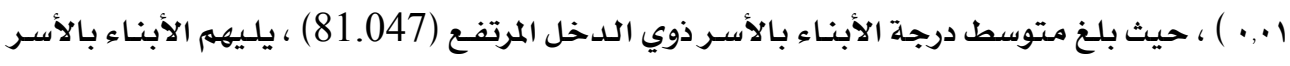


ذوي الـلـخل المتوسـط بمتوسط (61.760) ، وأخـيرا الأبنـاء بالأسـر ذوي الـدخل المنـخفض بمتوسـط

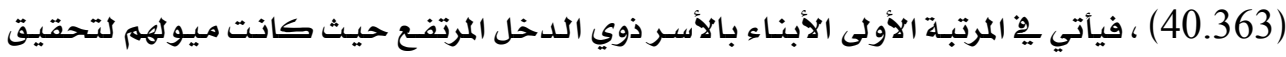

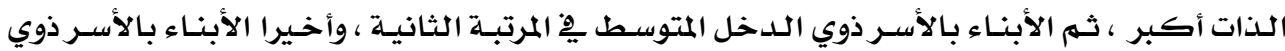

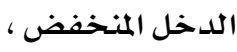
الثرض الثالث :

توجـد علاقـة ارتباطيـة بـين اسـتبيان اتجـاهـات الطالبـات نحـو العهـل بالمشروعات الـصغيرة واستبيان تحقيق الذات

وللتحقق من صحة هـذا الفـرض تم عمـل مصفوفة ارتبـاط بـين اسـتبيان اتجاهـات الطالبـات

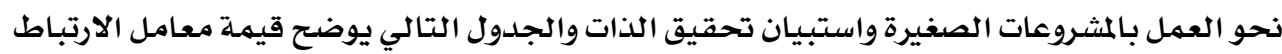
جدول (rr) مصفوفة الارتباط بين استبيان اتجاهات الطالبات نحو العمل بالمشروعات الصغيرة واستبيان تحقيق الذات

\begin{tabular}{|c|c|}
\hline تحقيق الذات & \\
\hline$* *,, \wedge \leq \Gamma$ & اتجاهات الطالبات نحو العمل بالمشروعات الصفيرة \\
\hline
\end{tabular}

يتضـح مـن الجـدول ( جr) وجـود علاقـة ارتبـاط طردي بـين اسـتبيان اتجاهـات الطالبـات نحـو

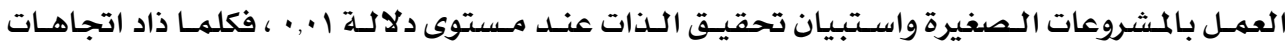
الطالبات نحو العمل بالمشروعات الصغيرة كلما ذادت قدرتهم علي تحقيق الذات

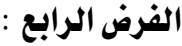

توجـد علاقـة ارتباطيـة بـين اسـتبيان اتجـاهـات الطالبـات نحـو العمـل بالمشروعات الصغيرة واستبيان تحقيق الذات ومتتغيرات الدراسـة

وللتحقق من صحة هذا الفرض تم عمل مصفوفة ارتباط بين استبيان اتجاهات الطالبات نحو العمل بالمثروعات الصغيرة واستبيان تحقيق الذات ومتغيرات الدراسة والجدول التالي يوضح قيم

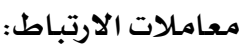


جدول (rV) مصفوفة الارتباط بين استبيان اتجاهات الطالبات

نحو العمل بالمشروعات الصغيرة واستبيان تحقيق الذات ومتغيرات الدراسة

\begin{tabular}{|c|c|c|}
\hline تحقيق الذات & اتجاهات الطالبات نحو العمل بالمشروعات الصغيرة & \\
\hline$* *,, 9, \wedge$ & $* *,, \wedge \wedge \wedge$ & عمر الطالبة \\
\hline$\cdot, \wedge r$ & $\cdot, 1 \leq r$ & الجالة الاجتماعية \\
\hline **, , १ץ & $* *$, , ^०. & 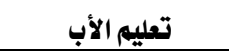 \\
\hline$* *, \wedge r V$ & $* *, \wedge \mid 1$ & تعليم الأم \\
\hline$* *, \vee \cdot\urcorner$ & $* \cdot, 7 \cdot r$ & 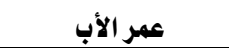 \\
\hline$*,, 7 \leq 1$ & $* *, \wedge \wedge r$ & عمر الأم \\
\hline$* *, \wedge \neg 7$ & $* *,, \vee \neg \wedge$ & مهنة الأب \\
\hline$* *,, \vee 9 \vee$ & $* *,, \vee \leq r$ & مهنة الأم \\
\hline$\cdot, 1 \cdot 7$ & $\cdot, Y \backslash V$ & علدد أفراد الأسرة \\
\hline$* *$, ,^৭ץ & $* *,, \vee \vee 0_{-}$ & الدخل الشهري للأسرة \\
\hline
\end{tabular}

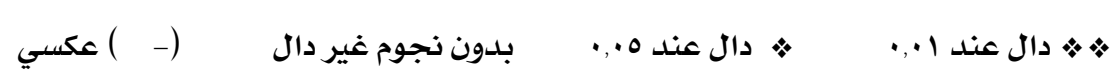

يتضـح مـن الجـدول (rv) وجـود علاقـة ارتبـاط طـردي بـين استبـيـان اتجاهـات الطالبـات نحـو

العمل بالمشروعات الصغيرة واستبيـان تحقيق الذات وبعض مـتغيرات الدراسـة عنـد مسستوى دلالهة ا .. ،

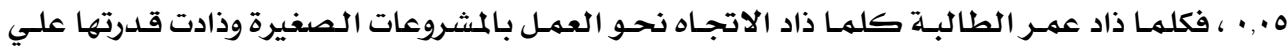
تحقيق الذات ، كذلك كلما ارتفـع المستوى التعليهي لكلأب والأم كلما ذادت اتجاهات الطالبـات نحو العمـل بـالمشروعات الـهغيرة وذادت قــرتها علـي تحقيـق الـذات ، كـذلك كلهـا ذاد عمـر الأب والأم كالهـا ذادت اتجـاهـات الطـالبـات نحـو العمـل بـالمشـروعات الـصغيرة وذادت قــرتها علـي تحقيـق الـذات ،

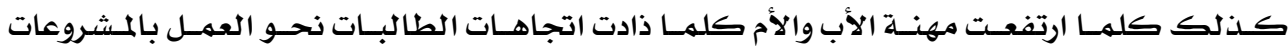
الـصغيرة وذادت قـدرتها علـي تحقيـق الـذات ، كـذلك كلهـا ذاد الـدخل الشهري لـلأسـرة كلهـا ذادت القـلـرة علـي تحقيـق الـذات ، بينهـا توجـد علاقـة ارتبـاط عكسي بـين اسـتبيان اتجـاهـات الطالبـات نحـو

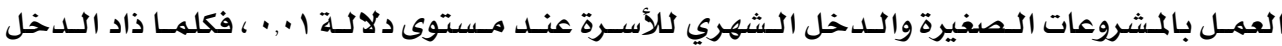
الشهري لـلأسـرة كلمها قل الاتجـاه نحو العمل بـالمشروعات الصغيرة ، بينهـا لا توجـد علاقة ارتبـاط بـين الحـالة الاجـتماعيـة وعـدد أفراد الأسـرة واسـتبـيان اتجاهـات الطـالبـات نحو العمـل بـالمشـروعات الهغيرة واستبـيان تحقيق الذات الافرض الخامس :

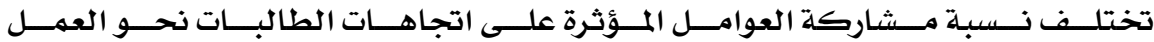
بالمشروعات الصغيرة 
وللتحقق من هذا الفرض تم حسـاب الأهمية النسبية باستخدام معامل الانحدار (الخطوة

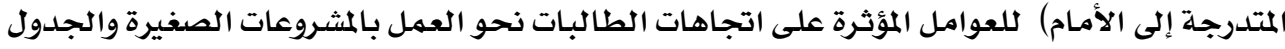

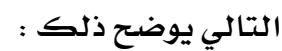

جدول (YN) الأهمية النسبية باستخدام معامل الانحدار (الخطوة المتدرجة إلى الأمام)

للعوامل المؤثرة على اتجاهات الطالبات نحو العمل بالمشروعات الصغيرة

\begin{tabular}{|c|c|c|c|c|c|c|c|c|}
\hline الدلالة & قيمة (ت) & هعامل & الدلالة & قيمة & نسبة المشاركة & الارتباط & المتفير المستقل & المتفير التابع \\
\hline$\cdot, \cdot 1$ & $\wedge, \wedge \circ \wedge$ & •, 71 • & $\cdot, \cdot 1$ & $V \wedge, \leqslant 79$ & - $\vee \wedge A$ & $\cdot, \wedge \wedge \wedge$ & عمر الطالبة & الطالبات نوه \\
\hline$\cdot,+1$ & $V, \xi+\eta$ & -, Orr & $\cdot,+1$ & $\Delta \leqslant, \wedge \leqslant V$ & •, Yrr & $\cdot, \wedge 0$. & تعليه الأب & العمل \\
\hline$\cdot,+1$ & $7, r \leqslant V$ & $\cdot, \leqslant \leqslant 9$ & $\bullet,+1$ & $\xi \cdot, Y \wedge\rceil$ & -, 7ov & $\cdot, \wedge 11$ & تعلييم الأم & \\
\hline$\cdot,+1$ & $0,\{\wedge r$ & •,rvr & $\cdot,+1$ & $r \cdot, \cdot 7 r$ & $\cdot, 019$ & $\cdot, \vee \vee \wedge$ & مهنة الأب & \\
\hline
\end{tabular}

يتضـح مـن الجـدول السـابق إن عمـر الطالبـة كـان مـن أكثر العوامـل المؤثرة على اتجـاهـات

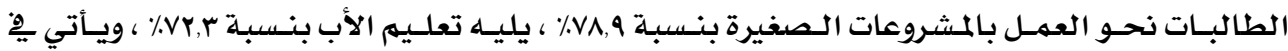

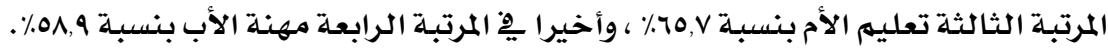

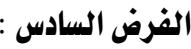

تختلف نسبـة مشاركة العوامل المؤثرة على تحقيق الذات

وللتحقق من هذا الفرض تم حساب الأهمية النسبية بـاستخدام معامل الانحدار (الخطوة

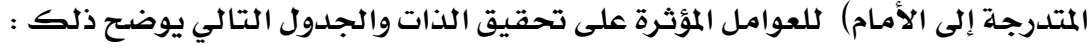

جدول (Y9) الأهمية النسبية باستخدام معامل الانحدار (الخطوة المتدرجة إلى الأمام) للعوامل المؤثرة على تحقيق الذات

\begin{tabular}{|c|c|c|c|c|c|c|c|c|}
\hline الدلالة & قيمة ( ت) & معامل & الدلالة & قيمة & نشبة & معامل الارتباط & المتفير المستقل & \\
\hline$\cdot, \cdot 1$ & $9,90$. & $\cdot, 701$ & $\cdot, \cdot 1$ & $99, \cdots+7$ & •, Aro & $\cdot, 9 \cdot 1$ & عمر الطالبة & التابع \\
\hline$\cdot, \cdot 1$ & V,qYV & $\cdot, 009$ & $\cdot, \cdot 1$ & Tr,Arr & $\cdot, r \leqslant q$ & $\cdot, \wedge 77$ & مهنة الأب & تحقيق \\
\hline$\cdot, \cdot 1$ & Y,VHI & •, §Vq & $\bullet,+1$ & $\{0, r+\uparrow$ & •, rar & •, ATr & تعليم الأم & الذات \\
\hline$\cdot, \cdot 1$ & $7, \cdot \& \cdot$ & •, हrT & $\bullet,+1$ & $\mathrm{rq},\{10$ & • , 7ro & •, var & مهنة الأم & \\
\hline
\end{tabular}

يتضـح مـن الجـــول السـابق إن عمـر الطالبـة كـان مـن أكثر العوامـل المؤثرة على تحقيـق

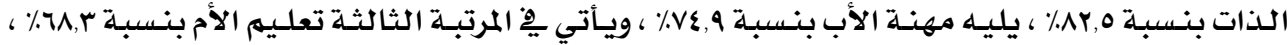

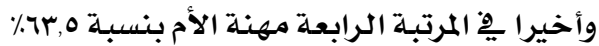




\section{التوصيات والمقترحات}

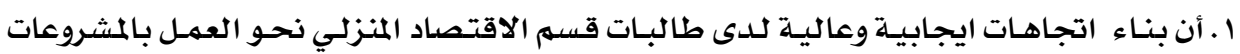

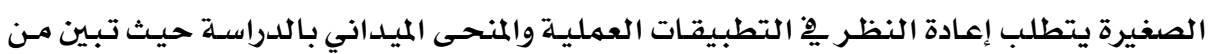

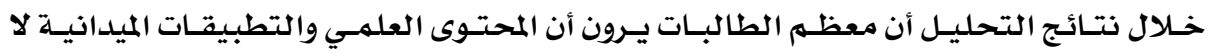

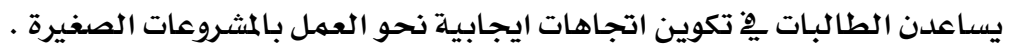

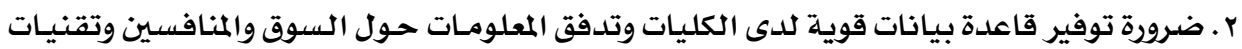

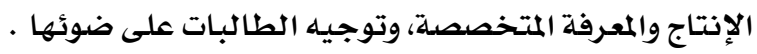

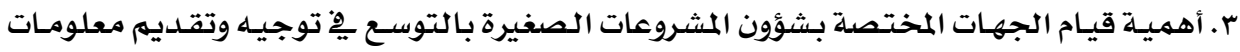

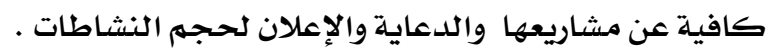

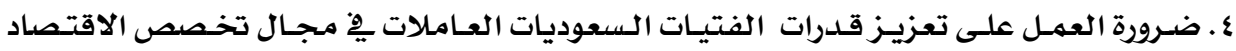

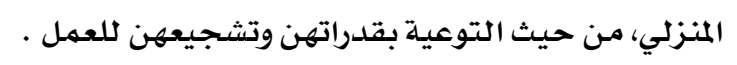

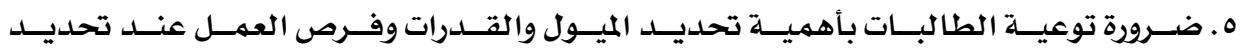
المشروع مستقبـلا.

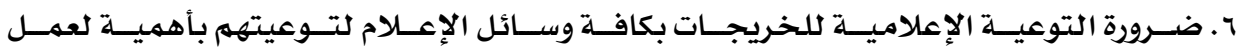
بالمشروعات الصغيرة.

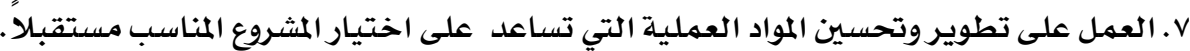

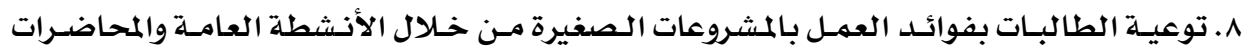

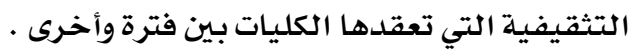




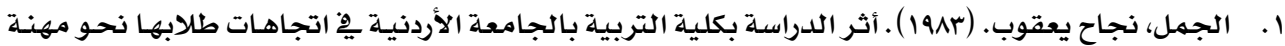

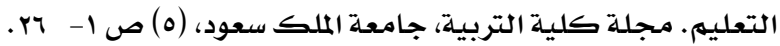

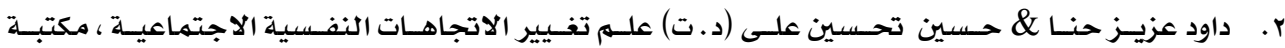

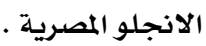

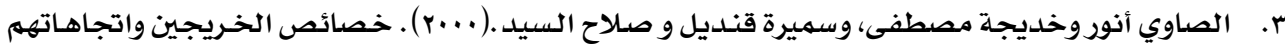

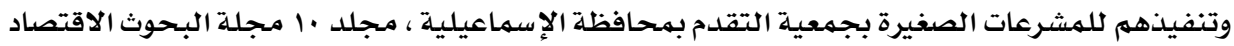

المنزلي ، جامعة المنوفية.

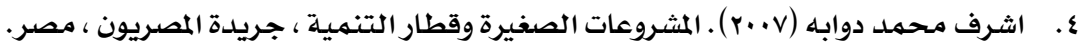

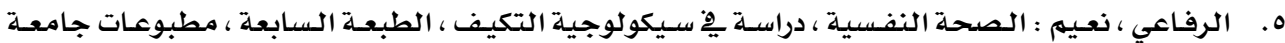

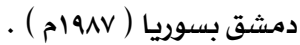

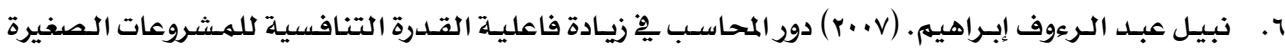

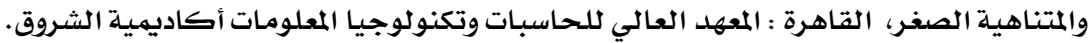

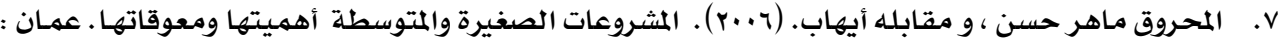

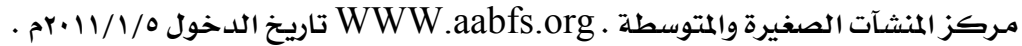

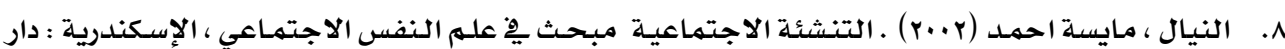

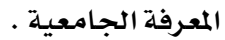

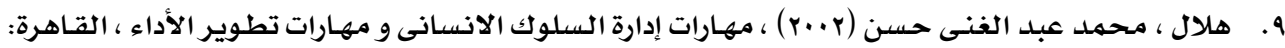

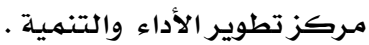

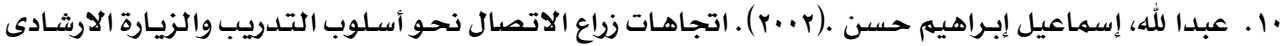

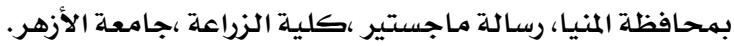

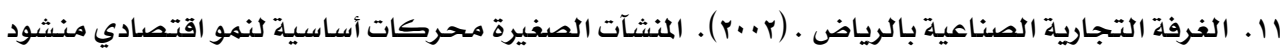

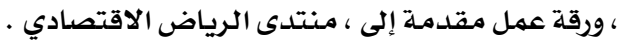

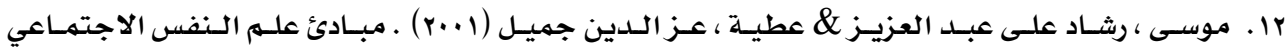

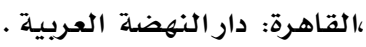

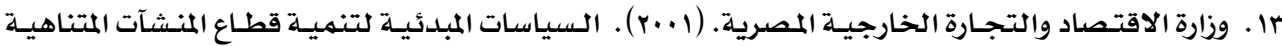
الصغر والصغيرة والمتوسطة يِ مصر.

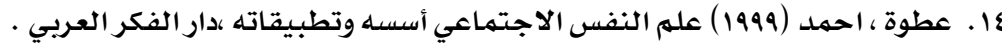

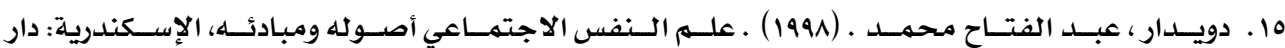

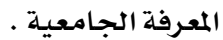
17 . . عبد الخالق، السيد أحمد (1994) المشروعات الصغيرة ِِِّ ظل التحولات الاقتصادية المحلية والعالمية، مجلـة البحوث القانونية و الاقتصادية. كلية الحقوق - جامعة المنصورة.أكتوبر، العدد \&؟. 


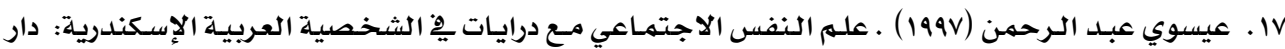

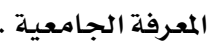

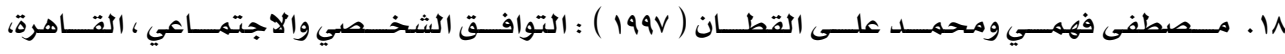
مكتبـة الخانجى

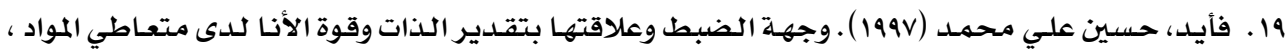
مجلة عله النفس، الهيئة المصرية العامـة للكتاب ،العدد بـع، القاهرة. •r . الصرايرة رياض ، وآخرون. (1991) . ورقة عمل حول إنشاء وتطوير المؤسسات الصغيرة والمتوسطة يغ الأردن،

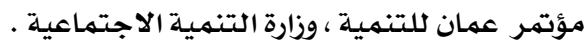

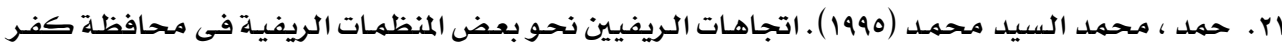
الشيخ ، رسالة ماجستير · جامعة عين شمس.

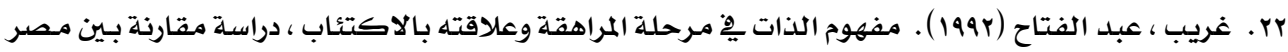
والإمارات العربية المتحدة ، بحوث المؤتهر الثامن لعلم النفس ، القاهرة: مكتبـة الأنجلو المصرية بـالقـاهرة .

. IIr-

rr. عبد الله عسكر ( 1991 ) : اختبـار تقدير الذات للمراهقين والراشدين ، القاهرة، الأنجلو المصرية.

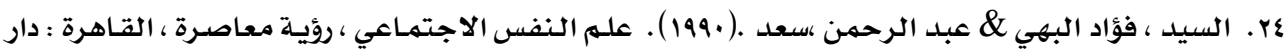
• الفكر العربي

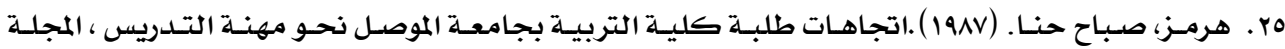

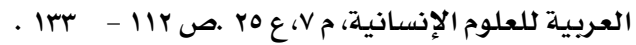

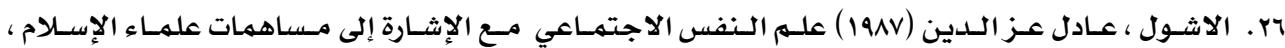

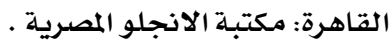
rV . زهران ، حامد عبد السلام • (1910) ) علم النفس الاجتماعي ،القاهرة : عاله الكتب.

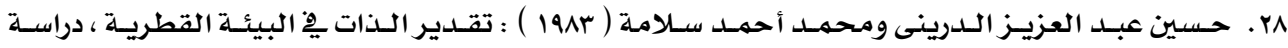

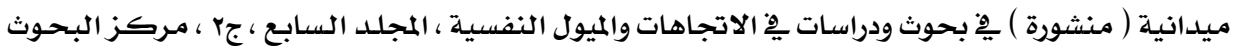

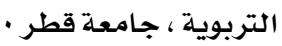

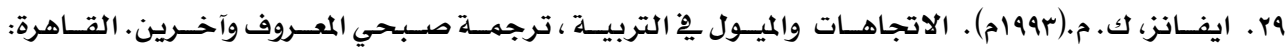
دار المعرفة.

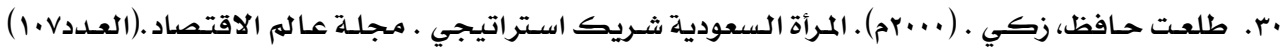
تاريخ الدخول http://www.ecoworld-mag.com

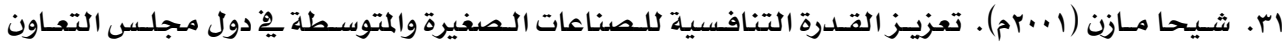

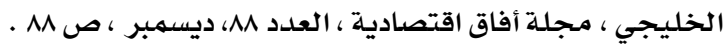

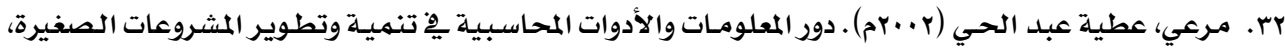
المجلة المصرية للدراسـات التجارية. . كلية التجارة - جامعة المنصورة. يناير،العلدد بr المجلد الأول.

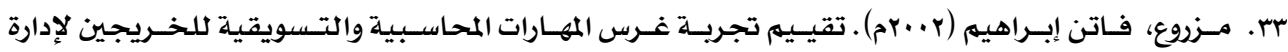

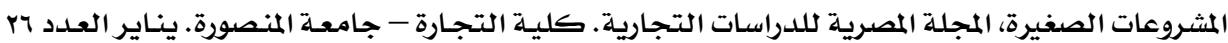




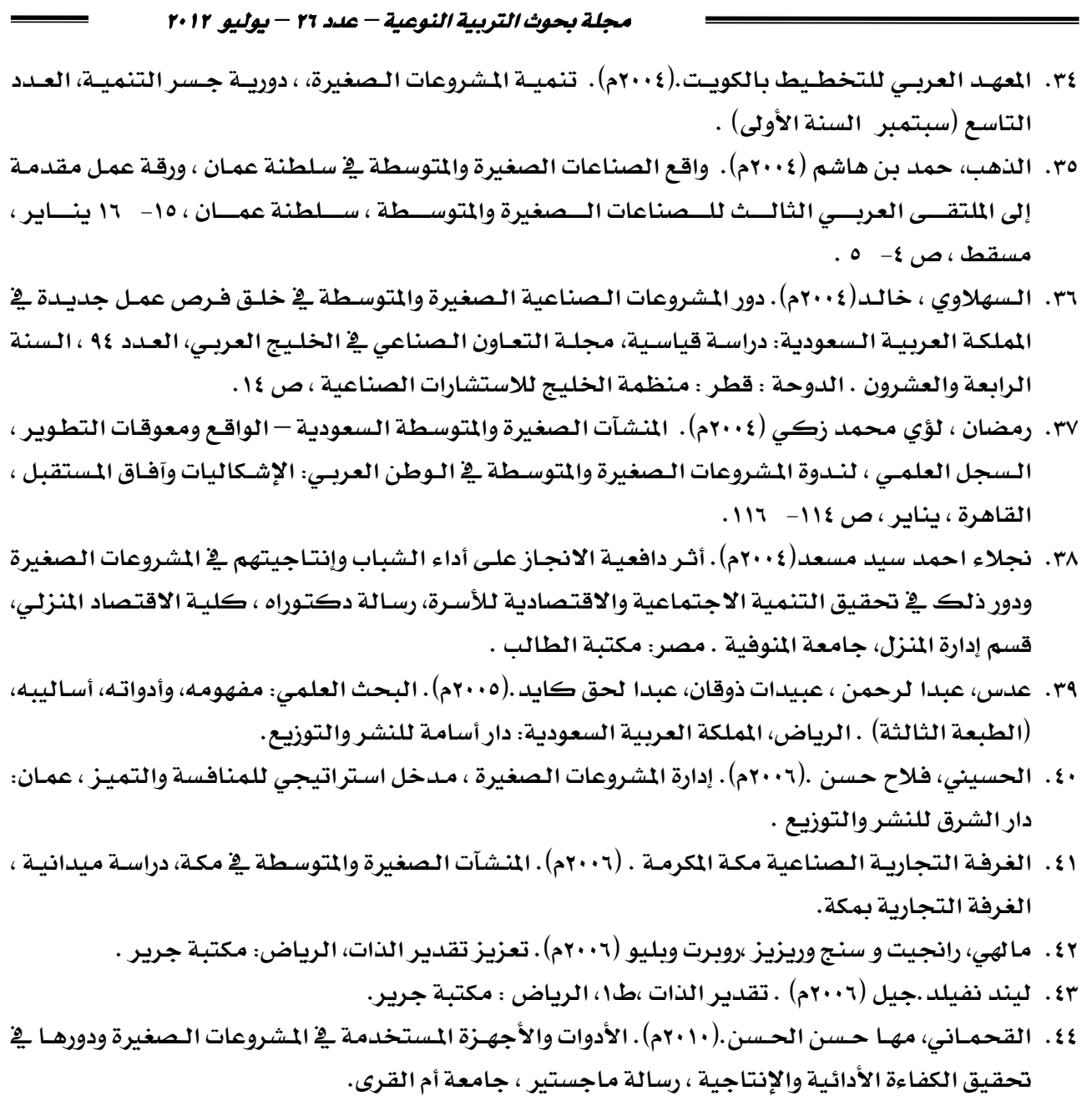

المراجع الأجنبية

45. English ,H. \& English , A. ( 1958 ) : Acomeprehensive Dictionary of Psychology Terms . New York . David Mokay Company . Inc, p. 138.

46. Mueller, J.D.(1986). Measuring Social Attitudes. New York; Teacher College Press. 